\title{
Once upon a time: uma história da História da Fotografia brasileira
}

\section{Ricardo Mendes}

Programa de pós-graduação do Depto de História da FFLCH-USP ${ }^{1}$
The title of the series of lectures of which this is one (Towards the new histories of photography - 1979 - Art Institute of Chicagol makes the assumption that there will be new histories of photography. It suggests seeing into the future - that is, seeing how the future will change the past. Of course, there will be new histories. The past is "there" to be reinterpreted. The new histories will be critical of past histories, and will reflect the concerns of future individuals. They will be fragments of autobiographies (CHIARENZA, 1982$, n. p. $)^{2}$.

Preâmbulo

O raciocínio desenvolvido por Carl Chiarenza (* 1935), em seu ensaio Notes toward an integrated history of picturemaking (1982) é curiosamente estimulante, considerando-se a defasagem espaço-temporal que se estabelece: EUA-Brasil - 1980-2003.

$\bigcirc$ pano de fundo do ensaio revela um campo de estudo amplificado, uma produção contínua marcada pela expansão de abordagens e tratamentos. Esse é, passados vinte anos, o panorama que começa a constituir-se no Brasil. Em seu texto, Chiarenza, propondo uma história da cultura visual Inão com essas palavras), aponta e reforça a cada momento seu foco: discutir como o conflito arte e fotografia se estabeleceu, e não, como poderia ser falsamente interpretado por leitores "apressados", se fotografia é arte. E essa dubiedade do próprio objeto de análise, que parece escorrer entre as mãos, obrigando que a abordagem seja continuamente reiterada, que me atrai e estabelece assim uma identificação com o autor.

\begin{abstract}
1.Este ensaio integra projeto de doutorado em andamento no programa de pós-graduação em História Social da FFLCH-USP intitulado $A$ invenção da fotografia brasileira: 1970-2000, sob orientação do professor doutor Nicolau Sevcenko.

2. CHIARENZA, Carl. Notes toward an integrated history of picturemaking. In: Reading into photograpby: selected essays: 1959-1980. Albuquerque: University of New Mexico Press, 1982. Publicado anteriormente em: Afterimage (SUMMER, 1979). Texto consultado em cópia xerox, não paginada.
\end{abstract}

3.Texto disponível em língua portuguesa, em edição brasileira, em antologias publicadas desde 1969 (Zahar), sendo a mais recente, reunindo exclusivamente ensaios de Walter Benjamin: $\mathrm{Ma}$ gia e técnica, arte e política (Brasiliense, 1985 1987, 3.ed)

4. Como diferenciação, toda referência à História da Fotografia, com inicial em caixa alta, deve ser en- 
tendida como aquela produção historiográfica estabelecida, sua corrente principal, que busca estabelecer a "grande história". É certa esta interpretação? Por enquanto deixemos assim, adotando-a como estratégia operacional.

5. Ferrez, Gilberto. A fotografia no Brasil e um dos seus mais dedicados servidores: Marc Ferrez. In: Revista do Patrimônio Histórico e Artístico $\mathrm{Na}$ cional, Rio de Janeiro,v. 10, p. 169-304, 1946

6. Um passeio a Petrópolis em companbia do fotógrafo Marc Ferrez. Rio de Janeiro: Museu Imperial, 1951;Album de Pernambuco:velhas fotografias pernambucanas, 1841-1900. Recife:Departamento de Documentação e Cultura, 1952.

7. Evidenciadora, por contraste, dessa situação, tão comum entre nós, foi a homenagem prestada pela FAAP por iniciativa de Pedro Vasquez e Rubens Fernandes Junior em 26.5.1998 ao conceder a Gilberto, em cerimônia íntima realizada em sua residência no Rio de Janeiro, um diploma de mérito por seus 90 anos de vida e em homenagem à sua atividade como historiador. Para sermos justos, Pedro Vasquez, que partilhou da experiência de Gilberto na última década em algumas montagens e edições de livros a partir de sua coleção, gerou há algum tempo depoimentos com o colecionador visando a produzir um panorama sobre sua carreira, mas ainda sem maior elaboração.

8. Abade Compte, a bordo da fragata L'Oriental, após passar por Recife e Bahia sem maiores conseqüências, realizaria em 16.1.1840 os primeiros daguerreótipos no Brasil, entre eles imagem do Paço Imperial. A expedição é usualmente apresentada na historio-
Chiarenza aponta a visão estreita dos historiadores da arte e da fotografia, pouco atentos ao ponto de contato entre os dois campos e acrescenta: "I daresay painters have always known more about photography than vice-versa and it has been to their advantage."

Como o leitor inferirá ao final deste ensaio, uma pergunta corre aqui por baixo de todo o texto sendo sempre deixada de lado, a da possibilidade de uma história da cultura visual. Este é um tema a ser desenvolvido em outro momento, mas é necessário apontar um aspecto "segregativo" da fotografia - interno e externo, uma ação de mão dupla, uma reação. Esse fenômeno abordado por Chiarenza em vários momentos está presente no contexto brasileiro e, em especial, no setor aqui estudado.

O isolamento da comunidade fotográfica em relação a outros segmentos da cultura é uma marca de longa data, centenária, no Brasil. Com certeza, não se expressa de forma homogênea se considerarmos que o termo comunidade fotográfica denomina uma realidade pouco solidária.

Se Chiarenza discute a possibilidade de uma história visual integrada e mantém-se persistemente a afirmar que não se interessa pela foło como arte, mas como tal questão se apresentou, faço desse mote um paralelo para o ensaio que agora se delinea. Não me interessa a história da fotografia (no Brasil), mas a história da história, sua consecução. Indo além, interessa entender a produção historiográfica como integrada ao campo do pensamento crítico, aspecto singelo que parece ter sido descartado ao longo dessa curta trilha de 30 anos como veremos.

Parece-me muito justo aproveitar uma citação de Walter Benjamin, de seu clássico A obra de arte na era de sua reprodutibilidade técnica $(1937)^{3}$, um dos raros textos teóricos que desde cedo marcam o pensamento brasileiro, citado por Chiarenza. "Benjamin wrote in 1937, 'The nineteenth century dispute as to the artistic value of painting versus photography today seems devious and confused. This does not diminish its importance, however, if anything it underlines it. The dispute was in fact the symptom of a historical transformation the universal impact of which was not realized by either of the rivals'. And he goes on to say, 'The primary question - whether the very invention of photography had not transformed the entire nature of art - was not raised.' "

De onde falo? Para onde vamos?

Talvez fosse o caso de apontar a partir de que ponto me situo: o do entendimento da fotografia como sistema integrado, abrangendo da produção à difusão (visual e do pensamento), da foto como objeto fotográfico, da valorização da cultura material adjacente e pertinente ao campo, das relações sociais cruzadas e multiniveladas e, enfim, da busca de enfrentamentos conceituais, ainda que quase imperceptíveis, mal formados, indeléveis.

O objetivo primeiro deste ensaio, mais apropriadamente uma reflexão pessoal, é de caráter programático: trazer os estudos da história da fotografia para o campo do pensamento, romper a ilha de Santa Cruz, imagem que poderia ser estendida ao campo da fotografia através de modos variados. 
objetivo segundo, de caráter eminentemente prático, é propor um esboço sobre "uma história bárbara da fotografia", que procure identificar a construção de uma História da Fotografia brasileira e sua eventual adesão / colaboração na construção de uma imagem para a Fotografia Brasileira latenção para as caixas altas, seu uso não é formall.

Assim, no primeiro momento, a intenção é estudar o estabelecimento de um campo de ação - o da história da fotografia no Brasil, sua gênese, suas dinâmicas e, talvez, suas cosmologias.

Ressalvo que ao focar uma História da Fotografia brasileira não procuro apontar ou delinear uma história oficial, ou ao menos oficialesca, embora o Estado através de ações únicas de agências como a Funarte pudesse agir nesse sentido. Se o fez, foi de modo indireto, irrefletido, mas de forma relevante, na qual alguns de seus agentes, seus "desejos", se identificavam, se confundiam com uma expectativa generacional. É a partir dali e sobre isto que procuro refletir.

\section{silêncio cultural}

A fotografia, não obstante sua presença imediata no País a partir de 1840, constitui-se aparentemente como um "não-objeto" no campo cultural, no sentido mais amplo. Ao longo do século XIX, sua percepção - como nos revela a História da Fotografia local ${ }^{4}$, é meramente funcional, como forma de produção do retrato ou como registro documental.

Nesta História há apenas traços do desenvolvimento da fotografia, roteiros pessoais de fotógrafos, trajetos, delineamentos de certas produções. Os estudos não identificam polêmicas, laudações ou qualquer outra forma de registro (não visual) sobre a fotografia. Ela parecer ser por si.

Mas deixemos de lado esse caminho. Vamos atrás de outro fio. De um gesto fundador, o do primeiro esforço em estabelecer um estudo historiográfico sobre a fotografia no Brasil. Vamos ao encontro assim da imagem de Gilberto Ferrez (* 1908 - + 2000). Ao final da década de 1940, Gilberto, herdeiro da coleção fotográfica produzida e formada pela atividade comercial de seu avô Marc Ferrez (* 1843 — + 1923), além de seu próprio interesse sobre iconografia brasileira, publica o ensaio A fotografia no Brasil e um dos seus mais dedicados servidores: Marc Ferrez. Editado na Revista do Patrimônio Histórico e Artístico Nacional em 1946, o texto ganha uma edição como separata sete anos depois 5 .

Será este o gesto fundador que uma historiografia sobre fotografia no Brasil elegerá quase 30 anos depois como referência. Em princípio, é compreensível essa filiação que alguns dos principais historiadores do setor como Pedro Vasquez (* 1954) e Rubens Fernandes Junior ( * 1949) adotarão. Exceto alguns raros artigos, aqui e acolá, dando conta de histórias setoriais como a memória de um fotoclube ou de um estabelecimento fotográfico isolado, nenhuma sistematização foi proposta com uma ambição maior, estendendo seu foco segundo um recorte temporal e geográfico mais abrangente.

Um ponto curioso, porém, é necessário apontar. $\bigcirc$ totem Gilberto nunca mereceu um estudo sobre sua contribuição específica à história da fotografia no Brasil. Totem, mas não tabu, Gilberto aparentemente surge como referência, mas isolado. grafia como organizada para divulgar o invento, sendo a embarcação apresentada como navio-escola, o que sempre nos deixara intrigados pelo fato de não haver registro de imagens realizadas nos dois primeiros portos brasileiros. Inexplicável silêncio, além do fato de nenhum esforço na direção contrária ter sido realizado: pesquisar a origem da expedição. A esse respeito, ver o esclarecedor artigo de R. Derek Wook (1994), disponivel na Internet:The captain Lucas and the daguerreotype in Sidney $<$ http://www. midleykent .fsnet.co.uk> (ver versão em português em <http:// www. fotoplus. com>). $\mathrm{O}$ autor reconstitui a formação da expedição, a carreira do capitão Lucas e do abade Louis Compte, inclusive recompondo a rota da embarcação (na verdade, dois navios). O ensaio permite inferir que a ausência de fotos em Recife e Salvador, em especial neste último porto, onde permaneceriam por mais de uma semana, certamente refletia uma escassez de material para experimentação,e mesmo no Rio de Janeiro, as mais de duas semanas antes do anúncio da realização das primeiras imagens talvez fosse uma clara evidência da intenção de garantir o acesso às autoridades em busca de maior visibilidade (comercial) da empreitada.A título de curiosidade, essa expedição atingiu - após alguns contratempos com o naufrágio de um dos navios - a Austrália, respondendo pelas primeiras imagens em daguerreotipia daquele continente.

9. Este fenômeno já fora em si precedido em meados do século XIX com as primeiras revistas ilustradas publicadas no Rio de Janeiro em especial, utilizando a litografia, um dos fatores que permitiram estabelecer uma cultura visual em maior escala, ainda que dis- 
tante da possibilidade da reprodução em massa da imagem fotográfica.

10.Apenas para evitar erros de interpretação: quando falamos em identidade o conceito não deve,em princípio,em primeira instância, ser confundido com o de uma fotografia nacional, mas sim como algo mais chão:o reconhecimento de uma produção local, distribuída pelo país, cujos "autores" se "vejam" como integrantes de uma comunidade, de comunidades.

11. Esta afirmação aponta para um fenômeno recente, cujo comentário escapa à esfera deste ensaio. Ela diz respeito a uma inserção ampla da fotografia no campo dos museus e mercado de arte contemporânea através de uma produção experimental,caracterizada pelo hibridismo de suportes, realizada por uma geração de artistas jovens, formada e educada num segmento mais próximo às artes visuais e vídeo do que às correntes tradicionais da fotografia documental. Tal processo, em desenvolvimento nos últimos dez anos, parece ter gerado pontos de atritos perante os representantes da corrente principal, o que mereceria ser melhor estudado e enfrentado.A ausência de debates deixa em aberto a possibilidade de uma ruptura. Obviamente este ponto de vista revela a faceta militante deste autor como agente cultural.

12. Este é um ponto que merecerá avaliação no projeto de doutorado em desenvolvimento pelo autor.

13. Como referência de trabalhos iniciais, ver: (a) o catálogo da mostra $A$ coleção do Imperador: fotografia brasileira e estrangeira do século 19 (CCBB, RJ, 29.1 a 23.3.1997); (b) transcrição do ciclo de palestras paralelo ao evento,
Sua produção editorial a partir de então é marcada, de início, pela fotografia. Edita pequenos ensaios, dos quais apenas alguns seriam relançados (em versões maiores) décadas após: Um passeio a Petrópolis em companhia do fotógrafo Marc Ferrez (1951, Museu Imperial) e Álbum de Pernambuco: velhas fotografias pernambucanas, 184 1-1900 (1952, Departamento de Documentação e Cultura-Recife) ${ }^{6}$.

No entanto, seus ensaios enfocarão nos anos seguintes a iconografia carioca como um todo, ou episódios ligados a outros núcleos como Recife. São estudos que poderiam ser definidos como o estabelecimento de uma literatura especializada buscando a identificação e mapeamento dos principais produtores e a circulação de acervos iconográficos, aspectos até então inéditos.

Em 1976, outra iniciativa envolvendo Gilberto surge como referência: a exposição Pioneer photographers of Brazil: 1840-1920, realizada em conjunto com Weston Naef, no Center for Inter-american Relations (Nova York/EUA). Remontada anos depois no MASP (SP, 1978) e no MNBA (RJ, 1979), seu catálogo se constituirá na única publicação sobre história da fotografia no Brasil da década de 1970.

O silêncio cultural sobre a fotografia ao longo de mais de um século de produção continuada e intensa entre nós parece suspenso, momentaneamente, com a ação de Gilberto Ferrez. Reunindo imagens, ampliando sua coleção, pesquisando autores e publicando, Ferrez constitui assim um repertório básico. Suas publicações, certamente, têm uma circulação irregular até a década de 1980, mas apresentam ainda outra peculiaridade: sua investigação sobre fotografia é paralela e de igual intensidade a aquela por ele realizada sobre a iconografia brasileira em outras mídias como a aquarela, a gravura ou o desenho.

Nenhum dos historiadores da primeira fase da História da Fotografia brasileira apresentará um perfil similar, ou mesmo uma familiaridade com aquelas mídias. Pior ainda, nem os historiadores de uma segunda fase, como comentaremos adiante, parecem ter dedicado atenção à obra de Gilberto, apenas à sua coleção, não como obra curatorial, mas como fonte imediata de imagens. Não-acadêmico, distante das novas práticas de estudos iconográficos que se estabeleciam intramuros, Gilberto permanecerá "esquecido"7.

Uma fotografia brasileira

Embora possa parecer um aspecto deslocado, é relevante comentar a noção de "fotografia brasileira" como uma identidade partilhada sobre a fotografia produzida no Brasil.

Excetuando alguns momentos isolados, por mais de um século desde a introdução da fotografia no País, em 1840, na mítica chegada de Compte ao Rio de Janeiro ${ }^{8}$, a expressão fotografia brasileira parece nunca ter sido proposta.

A ausência da simples significação advinda da expressão fotografia brasileira - uma identidade comum ou o reconhecimento como área de produção (para dizer o mínimo) - é um ponto não discutido. Como veremos adiante, após a década de 1970 o panorama será outro.

Ainda que a fotografia tivesse no século XIX seu lugar nas feiras comerciais, em particular eventos comemorativos como as exposições universais, 
em estandes dedicados às bellas-artes ou como publicidade de empresas ou propaganda de Estado - a questão de apresentar-se como una - uma fotografia brasileira - ou como manifestação nacional - parece não ter encontrado eco.

No campo restrito da fotografia, essa identidade como produção local talvez possa ter ocorrido na prática restrita a certos círculos. Seria o caso do movimento fotoclubista que desponta no País a partir de 1890 loutro tema esse, sem maiores estudos sobre desenvolvimento e relevância como conjunto), mas que terá maior desenvoltura em progressiva escala regional a partir do início da década de 1920, quando fotoclubes do sudeste (RJ, SP, PR) e de Porto Alegre começam a "fazer funcionar" um circuito de difusão de fotografias em expansão crescente. Será esse o primeiro sistema de difusão do setor a atingir um alcance nacional, que ganhará na década de 1940 um terreno maior ao inserir-se no circuito internacional. Circulam imagens, uma cultura visual, prêmios; mas ainda está por ser respondida a pergunta relativa à efetiva circulação de uma crítica consistente, oral ou escrita.

É necessário apontar que se faz aqui uma distinção diante da circulação pura e simples de imagens. A partir da primeira década do século XX o País verá surgir o fenômeno das revistas ilustradas que inauguram a fase de difusão em massa de um pré-jornalismo visual ${ }^{9}$. Neste ensaio, discute-se a presença de um circuito especializado de comunicação da fotografia, ciente porém de que o fenômeno das revistas ilustradas neste período ou das grandes revistas da década de 1950 é importante forma de estímulo para o agenciamento de novos profissionais e para a modificação do statu quo do sistema de produção de imagem e, mais ainda, do sistema fotografia.

Do ponto de vista do produtor (seria possível falar do ponto de vista do autor ?), o sentimento de uma fotografia brasileira, de uma "imagem" (projeto de identidade) na escala do nacional, só terá efetiva presença na década de 1980. Serão iniciativas como as semanas nacionais de fotografia que permitirão a circulação de informação de forma mais recorrente "na comunidade fotográfica" e na sociedade como um todo, e mesmo a circulação de pessoas e práticas, aspecto que até então tivera sempre alcance regional, quase local.

Sob esse aspecto a circulação de revistas especializadas brasileiras manteve um papel de difusão sempre de alcance regional, possivelmente restrito à área de ação econômica (e cultural) dos principais centros urbanos. É necessário deixar em aberto a hipótese de que o circuito fotoclubístico possa ter sido mais efetivo como forma de intercâmbio entre os praticantes, embora sujeito a visões preconcebidas (preconceitos, sob outras palavras) por parte de diversos segmentos da "comunidade fotográfica" (e mais tarde, de forma dilatada, pelo segmento cultural como um todo).

Afora as semanas nacionais, o quadro de formação (profissional ou não) e de difusão no setor sempre foi falho, irregular. $\bigcirc$ panorama, apesar das três décadas recentes, apenas ganhou nova configuração nos últimos anos: seja no ensino com graduações plenas ou seqüenciais, seja na pós-graduação como pesquisa acadêmica, seja no campo da memória através de novas iniciativas (Instituto Moreira Salles, por exemplo), seja no campo do intercâmbio, no qual o papel da Internet não foi efetivamente problematizado até agora.

que busca esta elaboração sobre o quadro da fotografia no Brasil? Apenas apresentar uma hipótese operacional: a produção de uma história da fotografia local encontraria ambiente para desenvolvimento, estando ausente a noção de identidade (dada ou auto-elaborada) do próprio segmento? com presença de Joaquim Marçal Ferreira deAndrade, Maurício Lissovsky, Lygia Segala,Annateresa Fabris e Lilia Schwarz, publicada em: Anais da Biblioteca Nacional, RJ, v. 117 , p. $7-$ 77, 1997.

14. A leitura inicial dos anais da Biblioteca Nacional a partir da década de 1890 indica um processamento lento da coleção Teresa Cristina, composta por outros gêneros documentais como cartografia e numismática. A seção de iconografia sofria de limitações severas em seus trabalhos, mas nada indica que fosse proibido o acesso ao material não efetivamente processado. Sobre a exposição de 1881 , ver $C a$ tálogo da exposição de História do Brasil. Annaes da Biblioteca Nacional do Rio de Janeiro: 1881-1882., Rio de Janeiro, (IX): [s.e.], 1881, $2 \mathrm{v}$.+ suplemento.

15. Embora pareça óbvia a filiação francesa, tal aspecto pode ter tido conseqüências inesperadas. Em investigação em desenvolvimento pelo autor sobre o panorama carioca do período, esta fonte-matriz pode ter gerado um campo distinto do debate sobre fotoclubismo e fotopictorialismo que se desenvolveria na Inglaterra, este sim apontado como local de maior tradição fotoclubística.Artigos da revista do Photo Club de Paris - $\mathrm{La}$ revue de photographie, disponível em bela coleção encadernada na biblioteca de História (FFLCH-USP) (e também na Biblioteca Nacional), cobrindo o período de 1903 a 1905 , apontam a expansão tardia do fotoclubismo na França (o que poderia explicar um desenvolvimento similar no Brasil, como também o debate tardio sobre o pictorialismo).

16. Deiró, Eunápio. A arte I. Kosmos, RJ, v.1, n.11, n.p., nov. 1904 . 
17. Este primeiro olhar sobre o fotopictorialismo tem lugar em parte através da segunda fase dos fotoclubes, ao final da década de 1930, a exemplo do Foto Clube Bandeirante; deu-se então em situação de confronto à "velha escola".

18. Outra peculiaridade do período é o desaparecimento gradativo de um perfil característico até a década de 1950 , o da presença do migrante, ou da primeira geração aqui radicada, em busca de novas possibilidades de realização econômica que não encontravam em seu País de origem. Uma parcela pequena destes recém-chegados ao país seria responsável nas décadas de 1930 e 1940 pela introdução de novas práticas em especial no fotojornalismo e publicidade. Esse importante vetor de renovação do setor daria assim lugar a um processo distinto de circulação de informação e atração de novos elementos.

19. Para não dizerem que não falei (de flores) é necessário levantar a hipótese de que a crescente prática social de protesto contra a ditadura militar acabou estabelecendo na sociedade civil a experiência associativa, gerando movimentos de amplo espectro. No segmento da fotografia, no período entre 1975 e 1985 surgiram desde propostas de discussão da fotografia como meio de expressão (movimento Fotogaleria no Rio de Janeiro e São Paulo) a várias iniciativas présindicais como o modelo da União dos Fotógrafos.

20. Viagem pelo fantástico. São Paulo: Kosmos, 1971 (prefácio de Pietro M. Bardi).

21. Projeto concretizado apenas em 1985: $A$ fotografia no Brasil: 18401900. Rio de Janeiro: Funarte/Pró-Memória,
É evidente que os estudos nessa vertente poderiam ter lugar de forma independente, mas sua expansão, sua retroalimentação seria muito restrita. Neste breve panorama do contexto da fotografia local, vale apontar que apenas na década de 1970 tem início uma efetiva discussão sobre fotografia no Brasil, e neste quadro a produção de uma história, a elaboração de uma memória ganha um sentido distinto. Talvez assim possa ser possível entender porque o gesto de Gilberto Ferrez permaneceu isolado por mais de uma década, não encontrando seguidores ${ }^{10}$.

\section{Ainda o silêncio cultural}

Se durante mais de um século a fotografia no Brasil não foi vista como segmento específico, em que a expressão fotografia brasileira poderia ser uma manifestação dessa visibilidade, por outro lado nada indica que a fotografia ao longo desse período partilhou das marcantes polêmicas ocorridas mais ao norte.

O conflito arte e fotografia, por exemplo, não parece ter gerado marcas evidentes, nem ao menos deixou traços escritos, como tudo leva a crer, caso leiamos a produção historiográfica brasileira sobre o setor. Sem enfrentar contestação, nem por isso quer dizer que a fotografia encontrou trânsito livre no terreno das bellas-artes. De forma curiosa, o seu desenvolvimento como meio de expressão aparentemente se deu em paralelo, sem maiores contatos, ao das artes visuais. A história do fotoclubismo brasileiro na primeira metade do século XX é um belo exemplo. Mais curioso ainda se notarmos que nos eventos promovidos então se registra aqui e ali a presença de participantes ligados às bellas-artes; além disso, salões são abertos com a presença de governadores e mesmos críticos de arte, e ainda assim, os processos históricos destas mídias visuais (e suas historiografias) têm lugar em separado, sem se tocarem (aparentemente).

Aqui, espero que ganhe sentido o preâmbulo ao redor do ensaio de Carl Chiarenza. A história da fotografia no Brasil foi contada até agora a partir de dentro, entre seus pares, a partir da luta por uma inserção em contexto cultural maior. Não se ouviu atentamente, não se olhou nas entrelinhas o que além muros se fazia e assim ganha maior valor a afirmação de Chiarenza: "I daresay painters have always known more about photography than vice-versa - and it has been to their advantage." Este aspecto pode explicar muito da atual situação da fotografia no Brasil, da sua inclusão (implosiva) ${ }^{11}$.

ovo ou a serpente: uma pré-história

Mas se não "existe" formalmente uma história da fotografia no Brasil antes do marco representado por Gilberto Ferrez - ou mais efetivamente antes da década de 1970, quando ela surge com todas as letras - existe uma pré-história. Rica, diversificada e ignorada, embora isolada pelo olhar da historiografia, por sua corrente principal.

Existe, indo além, uma pré-história da historiografia e do pensamento. Se a ação dos documentalistas, das primeiras cronologias, permanece restrita a episódios, como os artigos na década de 1940 de Eduardo Salvatore, presidente 
por longa data do FCCB - Foto Cine Clube Bandeirante, registrando o momento anterior à formação do fotoclube, alguns instrumentos de pesquisa começavam ainda assim a ser delineados por essas e outras ações.

No campo paulistano seria fundamental o período entre 1900 e 1920, em que ocorreria o que denomino primeiro boom editorial sobre a memória paulistana. Esta ação é cristalizada através de formas variadas, da edição de álbuns que reuniriam as primeiras imagens sobre a cidade ao projeto de A. Taunay, no Museu Paulista, de estabelecer (ou melhor, construir efetivamente) uma iconografia paulistana, através de pinturas tendo como referência a fotografia, fazendo assim uso de gestos bem conhecidos atualmente - cópia, edição e fusão de imagens fotográficas.

No caso carioca, de forma emblemática, a doação na década de 1890 da coleção do imperador Dom Pedro II caracteriza um gesto único, que não foi efetivamente analisado até o momento. Seria relevante pensar, dentro do quadro de silêncio cultural apontado no início do ensaio, quão estranha é em si a existência dessa coleção entre nós.

Pode-se perguntar se a ação de Pedro não era um mero gesto isolado, sem eco na sociedade de então. Seus contemporâneos tinham idéia de seu interesse? $\bigcirc$ gesto (de colecionar e, indo além, doar) tinha relevância cultural, tinha significado? Era visto como um modelo? Não acredito que perguntas nesta direção tenham sido formuladas nos estudos surgidos ao final do século XX $X^{12}$.

Para evitar entender (ou dar a entender) que a coleção Teresa Cristina fosse apenas a manifestação de uma perversão do imperador, um desvio, seria possível levantar uma hipótese inicial, a de que o modelo adotado por Pedro não seria diferente do adotado por outras coleções pessoais locais: a troca de retratos, a compra de estampas do País e do exterior, por exemplo. Apenas ressalvando que o modelo se realizava num contexto de maior afluência, de maiores trocas (em que a figura do imperador seria o foco de atração) e no registro único de erudição pretendido por Pedro. Posto isso, a máquina-coleção passaria a funcionar por si própria, revelando-se talvez ao imperador como um novo empreendimento. No entanto, aparentemente os estudos sobre a coleção não avançaram além da preservação e identificação do conjunto; eles não se estenderam até seus diários pessoais, aos livros de registros de compras, de presentes à Coroa, não estabeleceram a dinâmica de seu crescimento (e progressiva valorização simbólica) ${ }^{13}$.

Mas isso não importa. $\bigcirc$ fato único que se impõe é que o País possuía ao final do século XIX uma coleção pública de imagens fotográficas sob a guarda de uma biblioteca de livre acesso. Nem por isso um século novo que se iniciava, tendo um repertório visual de tal monta abrigado numa instituição que já em 1881 , realizara uma mostra de porte sobre história do Brasil na qual a fotografia teve presença marcante lembora este autor desconheça uma avaliação efetiva sobre esse evento, seja sobre seu conceito, seja sobre o recorte temático, seja, enfim, sobre o impacto no público e na produção posterior), nem por isso houve qualquer sinal em direção ao início de uma historiografia sobre fotografia no País ${ }^{14}$.

Silêncio por um lado. Por outro, algo se move. No campo da ação prática tem lugar então um fato único, que merece lembrança neste quadro. A fotopintura ganha adeptos contínuos na última década do século XIX. Artigos começam a pipocar, anúncios oferecem aulas de diferentes processos para o retrato que abusam da fronteira entre pintura e fotografia. Este quadro que poderia ser facilmente nomeado de "baixa cultura" reflete uma prática que se dá com
1985. Foi lançado cinco anos depois nos EUA pela University of New Mexico, o que lhe garantiu alguma visibilidade internacional, considerando-se o usual padrão editorial do setor restrito à língua pátria.

22. Organizado porWalter Zanini para o Instituto Walther Moreira Salles e a Fundação Djalma Guimarães.

23. Criado em 1970, o museu passou a atuar mais efetivamente em 1975 após inauguração da atual sede.

24. Embora a história não se escreva com condicionais, quais seriam então as possibilidades alternativas rumo a uma história integrada à grande história da arte?

25. Este projeto geracional é o foco do projeto de doutorado em "história social" em desenvolvimento pelo autor: $A$ invenção da fotografia brasileira: 1970-2000.

26. Autor da divertida e completamente incompreensível obra Em torno da fotografia no Brasil (São Paulo: Banco Sudameris, 1987), que acredito mereça uma reavaliação de sua forma invulgar, quase uma longa conversa sobre o tema, um convite ao diálogo.

27. A este respeito, ver LIMA, Solange Ferraz de. São Paulo na virada do século: as imagens da razão urbana - a cidade nos álbuns fotográficos de 1887 a 1919. 1995. Dissertação (Mestrado em História Social) - Faculdade de Filosofia, Letras e Ciências Humanas, Universidade de São Paulo, São Paulo, 1995.

28. A fotografia aqui era vista como documento central, como fonte documental relevante para a his- 
tória urbana. No entanto, tudo o mais era negado.A recuperação de informação estava restrita ao índice dos logradouros registrados, sendo as imagens organizadas de forma comparativa em termos cronológicos estritos. Nem autores (apesar da prática de registro dos créditos autorais das imagens contemporâneas), nem os motivos e funções que geraram os registros, nem os conjuntos originais podiam ser recuperados. Ainda assim o acervo era único como espaço de trabalho, embora o modelo organizacional constituísse um severo impedimento ao desenvolvimento de estudos sobre as relações entre fotografia e cidade. Merece atenção a referência ao Arquivo de Negativos no clássico ensaio de Ferrez, de 1946, que destaca o serviço realizado por Benedito Duarte na instituição. Em especial, porque Ferrez neste ensaio não valoriza especificamente as coleções em acervo, nem faz sequer menção à coleção do imperador: "Graças a ele" referindo-se à produção de Militão Augusto de Azevedo - "e outros que surgiram mais tarde, pôde o $\mathrm{Sr}$. Benedito Duarte, diretor da Seção de Iconografia da Divisão de Documentação Social Estatística de São Paulo, organizar um arquivo fotográfico provido de fichas elucidativas e eruditas, de grande valor para os pesquisadores. Esse trabalho deveria servir de padrão a todas as grandes cidades brasileiras, que não poderão prescindir, no futuro, de tão relevante serviço" (FERREZ, 1946, p. 241).

29. O termo empregado no segmento a partir da década de 1980 seria fotografia como expressão pessoal.

30. Registre-se a pioneira ação desenvolvida já em 1970 no MAC-USP nesta outra dimensão nos países ao norte: o do fotopictorialismo, que encontrará entre nós praticantes associados aos primeiros movimentos fotoclubistas locais com forte informação internacional, de modelo francês ${ }^{15}$.

Assim, na primeira década de 1900, artigo de Eunápio Deiró, em $\mathrm{Kosmos}^{16}$, parece ser a ponta do iceberg. Informado sobre a produção francesa, o autor discute seus pontos de vista ante a relação fotografia e pintura. Define-se aqui, com tantos anos de atraso em relação a outros contextos, a primeira manifestação da fotografia entre nós que se reinvidica como arte.

Essa menção é necessária, pois define um momento programático da fotografia no Brasil, aspecto até então desconhecido, que se "realizará" através dos fotoclubes. A história do desenvolvimento do fotopictorialismo não nos interessa agora, nem em "seus acertos e seus erros"; quando muito, seria relevante para nós a interpretação posterior, a historiografia que se estabeleceu negativamente sobre esse episódio, cujos autores tinham como referência uma outra fotografia e assim "não podiam ver" o que acontecera"

Uma nova história: primeira dentição - anos 70

Uma figura que me parece tão cara aos antropólogos, a do fenômeno social total, é facilmente reconhecida no campo da fotografia. O texto clássico de Gisèle Freund - Photographie et Société (1974), uma das raras referências bibliográficas disponíveis na década de 1970, que circulou amplamente no Rio de Janeiro e em São Paulo em sua edição espanhola pela Gilli de Barcelona, La fotografia como documento social (1976), partilha em sua estrutura de uma interpretação esclarecedora do conceito. E, neste período que nos interessa, o fenômeno revela-se momentaneamente perante toda uma geração.

A década de 1970, no que toca à fotografia, representa um momento de pura efervescência, aspecto não devidamente analisado até hoje. Essa situação tem sido vista, em parte, como reflexo de um "redescobrimento" da fotografia no quadro internacional.

Mas diante de um período em que as escolas de fotografia eram empresas instáveis, projetos de alto risco propriamente, em que bibliotecas conviviam com parcos recursos, a mera importação de livros e revistas sofria restrições e nem ao menos o País se incluía no circuito de mostras internacionais - como em tal contexto este reflexo internacional poderia ser apresentado como explicação?

Duas possibilidades devem ser apontadas como vertentes de análise sobre o momento. Ocorre uma renovação no perfil dos jovens participantes no segmento, em que se destacam os egressos de uma classe média urbana, muito deles com formação universitária, o que em si contrastava com o perfil tradicional dos praticantes em qualquer setor fotográfico apenas uma geração antes. Além disso, estes novos associados tinham algum acesso a livros e revistas estrangeiras, e, em certa parte, uma minoria deste grupo, durante aquela década, cairia na estrada - de Paris a São Francisco ${ }^{18}$.

Um último aspecto merece ser acrescentado para caracterizar o panorama de fundo em que esta efervescência tinha lugar. Implantavam-se naquele momento novas modalidades de comunicação de alcance nacional, as redes de televisão, em especial, gerando impactos no campo maior do jornalismo le da 
publicidade). Havia uma reestruturação dos grupos de comunicação e assim, queiramos ou não, uma nova imagem do País era constituída. Não seriam os fotógrafos nem os publicitários que permaneceriam indiferentes à nova "situação"19.

Em meados dos anos 1970, algumas ações sobre a História da Fotografia têm lugar. A retrospectiva realizada por Ferrez e Naef em 1976 em Nova York chega a São Paulo (1978) e Rio (1979). Boris Kossoy (*1942), arquiteto e fotógrafo, autor de um dos primeiro livros fotográficos, segundo o conceito que seria adotado desde a década de 1940 nos países ao norte ${ }^{20}$, passa a manter uma coluna mensal sobre fotografia em $O$ Estado de S.Paulo. No contexto carioca surge em agosto (tão emblemático mês) de 1979 o Núcleo de Fotografia da Funarte, que não muito depois já estabeleceria como projeto editar o clássico A fotografia no Brasil, centrado na coleção de Gilberto Ferrez ${ }^{21}$.

A presença de Boris Kossoy é marcante no período. Sua persona pública identifica-se solidariamente com a pesquisa em fotografia no Brasil. Seus artigos em $O$ Estado de S.Paulo traçam o perfil de personalidades locais como Hércules Florence ou Valério Vieira.

Em 1975, Kossoy publica na série editada pelo mesmo jornal Suplemento do Centenário - o ensaio Panorama da fotografia no Brasil desde 1832 (18.10.75). Seria seu primeiro texto longo sobre o tema. Em 1976 lança a pesquisa Hércules Florence: 1833: a descoberta isolada da fotografia no Brasil, pela Faculdade de Comunicação Anhembi, reeditada em 1980 pela Livraria Duas Cidades. Em 1978 defende seu mestrado sobre Militão Augusto de Azevedo na Escola de Sociologia e Política, e no ano seguinte o doutorado, na mesma escola, que dará origem ao livro editado em 1980 pelo Núcleo de Fotografia da Funarte: Origens e expansão da fotografia no Brasil. A edição, em 1983, do texto de 1980 sobre fotografia na enciclopédica História geral da arte no Brasi22, completará o panorama de sua autoria sobre a fotografia no Brasil de 1833 a 1980.

momento é rico. A abertura efetiva do MIS paulistano - Museu de Imagem e do Som -, em $1975^{23}$ (do qual Boris seria o diretor entre 1980 e 1983) introduz, em São Paulo, um modelo de memória para as novas mídias, um modelo integrativo que não se realizaria (e que merecerá um comentário mais adiante).

perfil de produção de Kossoy nestes 10 anos é claramente orientado para duas vertentes: a constituição de panoramas historiográficos, valorizando a fotografia como fonte documental numa abordagem mais próxima da história social, e o estudo aprofundado de autores como Florence e Militão. Nesta linha, seu trabalho nada tem de original, tais fotógrafos eram figuras notórias. $\bigcirc$ marco está em tratá-los sob forma de pesquisa sistemática, de recuperação de fontes, de reconhecimento dos objetos no campo da História. No tocante aos ensaios panorâmicos, Kossoy produz, afora o marco representado por Ferrez, os primeiros textos de maior abrangência temporal, influenciados em parte pelos três vetores referenciais da história da fotografia do período: Gisèle Freund, Beaumount Newhall e Helmut Gernsheim.

A abordagem desses ensaios aponta, como comentado acima, para dois aspectos: a valorização autoral e a documentação sobre o território geográfico e sua ocupação. Autor informado, Boris não renega aspectos como a inserção da fotografia no campo cultural, sua importância documental e simbólica; mantém, contudo, o foco destes temas a partir do campo da fotografia, a partir de um enfoque unilateral. direção, com debates públicos e início efetivo de sua coleção fotográfica.

31. E mesmo este panorama épico era em si novo, pois começava a ser reunido, exposto, a ganhar uma nova vida.

32.A denominação do departamento revela em parte, embora não tenha sido investigada adequadamente sua origem, o perfil de Vasquez, que propôs a criação da coleção de fotografias da entidade. Formado em cinema na França em meados da década de 1970 , é naquele país que efetivamenteVasquez inicia sua prática fotográfica, expondo, editando seu primeiro livro $A$ la recherche de l'Eu-dorado (Paris: Contrejour, 1976) e descobrindo, como toda a sua geração, os encontros fotográficos de Arles. Sobre a proximidade de mídias expressa na denominação do departamento, esta abordagem não encontra expressão direta na prática historiográfica de Vasquez sobre fotografia brasileira. No entanto, ele partilha hoje de uma visão integrada da fotografia com as artes visuais, não postulando (conforme depoimentos ao autor ao longo de 2002) a necessidade de instituições espe-cializadas como o Instituto Nacional de Fotografia, do qual foi diretor e organizador

33. Entenda-se o argumento como constituição de um interesse partilhado por uma comunidade em escala nacional e não como sentimento de uma "fotografia nacional".

34. Seria relevante mencionar que no curto período como diretor do Departamento de Fotografia, Vídeo e Novas Tecnologias do MAM, justamente aquele em que a entidade permaneceria fechada em conseqüência do incêndio,Vasquez organizou 
no exterior mostras coletivas sobre fotografia contemporânea brasileira $\mathrm{e}$ mostras históricas (Miroir rebelle, Paris, 1986; La Photographie Brésilienne au dix-neuviéme Siécle, Paris, 1986, remontada em Houston e Novo México, 1988).

35. Iniciativa que se contrapunha como alternativa ao Arquivo de Negativos, o qual não se renovara, situação em que se encontra ainda hoje.

36. Para uma avaliação da produção editorial brasileira no setor seria possível recomendar a consulta ao site mantido pelo autor - <http:// www. fotoplus.com/ database $>$, que disponibiliza duas bases de dados, uma bibliográfica, outra de eventos.

37. Neste último aspecto, a questão deveria avaliar o processo não como um espelhamento, mas como busca de inserção em horizonte mais amplo. Até mesmo seria o caso de propor esta aproximação com a América Latina como pressão advinda do panorama internacional, fato evidenciado pela ocorrência de mostras organizadas no exterior voltadas para o contexto latino-americano como um todo. Eventos internacionais sobre fotografia brasileira, promovidos a partir de iniciativas externas, parecem despontar apenas na década de 1990 , com a exposição Brasilien: Entdeckung und Selbstentdeckung, em Zurique (1992).Ainda assim, como este exemplo revela, os organizadores contaram com a cooperação de brasileiros, como Stefania Bril e Angela Magalhães. Seria o caso de reavaliar a mostra Brésil des Bresiliens, no Pompidou (Paris, 1983), para rever o grau de autonomia, fonte de financiamento..
A recepção a esses textos, potencializada pelo lançamento de Origens e expansão da fotografia no Brasil pela Funarte, então foco de difusão extremamente ativo (talvez um exemplo da ação certa na hora e local certos), bem como o reconhecimento internacional de Kossoy nos anos seguintes a partir da pesquisa dedicada a Florence, todos esses aspectos definirão um locus consistente para seu autor, ainda que no final da década de seguinte Kossoy promovesse uma reorientação de sua produção e tivesse, em novo contexto, menos visibilidade.

O modelo Boris Kossoy poderia ser entendido como o da história da fotografia como atividade especializada. Ao mesmo tempo representa uma estratégia operativa "necessária" para estabelecer uma historiografia sobre um campo em busca de reconhecimento 24 . Sob esse aspecto seria válido perguntar as razões de uma aceitação tão plena de tal produção historiográfica.

Uma resposta possível estaria primeiro no público novo que se apresentava, como comentamos anteriormente. Um público - tanto no que toca aos novos profissionais como aos novos [consumidores] - com formação (visual) mais qualificada, mais amplificada. Mas antes de tudo, partilhando um objetivo claro: um projeto geracional, o de buscar a inserção da fotografia como meio de expressão e documentação no quadro cultural brasileiro ${ }^{25}$.

Assim, os panoramas propostos por Boris podem ser apropriados como uma referência histórica, como um passado, uma tradição, por parte desses novos agentes da fotografia.

Seria relevante talvez apontar que esses ensaios enfatizavam a descoberta imagética de um novo país-continente, o que evidentemente devia fazer eco às ações propostas por novos fotógrafos interessados na documentação material e humana do País em fase de grandes transformações, sob as janelas renovadas dos jornais e das redes de televisão.

Curiosamente, a produção visual mais experimental permanecerá em segundo plano, a busca da face do brasileiro ocupa o foco dominante. Nem mesmos aqueles ensaios históricos enfocavam tais gêneros de produção mais experimentais, não-documentais. Afora as valorizadas fotomontagens de Valério Vieira, "absorvidas" mais como perícia técnica, pelo contraste com a produção geral, e (afora) o parco panorama sobre o fotoclubismo (sem que a historiografia destaque, lembre-se, sua produção - o fotopictorialismo), a tônica era documental.

O panorama aqui traçado marca a primeira etapa do que seria possível apontar como a fase inicial de elaboração do campo operacional da história da fotografia no Brasil. E, segundo nossa hipótese, a forma como tal História se coadunou com o esforço geracional em busca do reconhecimento da fotografia no quadro cultural brasileiro. Agora, a fotografia brasileira é apresentada com todas as letras; pela primeira vez, ousa-se dizer seu nome.

Um aspecto vital nesse processo diz respeito à necessidade de constituição de acervos, de centros de memória. Neste quadro o surgimento do modelo MIS, implantado no Rio em 1965 e em São Paulo, cinco anos depois, é um marco distintivo.

Até então a existência de acervos fotográficos era uma exceção. Ainda que formalmente constituída, a coleção Teresa Cristina não tinha visibilidade e acesso. Datam de meados da década de 1980 as primeiras exposições e ações sobre processamento da coleção em moldes contemporâneos. No caso paulistano, a situação era mais grave, pois nenhuma instituição - tanto as históricas como o Museu Paulista-USP, como aquelas dedicadas às artes como MASP ou MAM possuía coleções fotográficas efetivamente. Em raros casos na década de 1970, os 
conjuntos de imagens existentes eram parasitários ao resto do acervo. O MASP recolheria nos anos 50 e 60 um grande conjunto de imagens - retratos e vistas, mas este material atendia mais ao interesse pessoal de Pietro Maria Bardi26, sem estar processado ou integrado ao acervo. O Museu Paulista mantinha um repertório de imagens relacionadas ao projeto de Taunay, constituindo assim seu núcleo fotográfico mais importante, sem ser, no entanto, um material de destaque ou com autonomia na coleção geral la qual, na verdade, passaria por severas remodelações, em especial na gestão de Ulpiano Bezerra de Meneses no início da década de 1990).

Ainda no tocante à memória documental, apenas dois núcleos têm relevância, então, em São Paulo: a Biblioteca Municipal Mário de Andrade, pelo conjunto de imagens presentes no setor de Obras Raras com registros associados à ação de Washington Luiz ${ }^{27}$ quando prefeito da capital paulista, e o Arquivo de Negativos, unidade do Departamento do Patrimônio Histórico (DPH/SMC), organizado na década de 1940 por Benedito Duarte, talvez o único arquivo fotográfico público que mereceria ser assim identificado naquele momento ${ }^{28}$.

No tocante à fotografia como expressão29, entre a década de 1970 e meados da seguinte ocorrem as primeiras tentativas de constituição de acervo em instituições como MAM-SP, MAC-USP e MASP, mas de forma incipiente ${ }^{30}$. Apenas na década de 1980 o MAM carioca constituirá efetivamente a primeira coleção (nas duas vertentes, documental e expressão pessoal), projeto interrompido em sua forma original, mas com saldo positivo, o que garantirá sua retomada.

Nesse esforço constitutivo, o interesse por arquivos fotográficos leva à recuperação de um conjunto de imagens geradas por serviços de infra-estrutura urbana, como o caso da Light paulista ou do serviço documental municipal, no caso carioca, realizado por Augusto Malta (incorporado, em parte, ao MIS carioca na primeira hora, e também ao acervo do Arquivo Geral da Cidade).

Insistimos no ponto: a primeira fase da História da Fotografia brasileira aqui proposta segue o modelo do historiador da fotografia, como especialização, como agente único. $\bigcirc$ foco dos ensaios resultantes é o autor, o fotógrafo, e muito raramente o sistema de produção e circulação de fotografia como um todo. Procurase organizar os discursos visuais, formar acervos, estabelecer cronologias.

Tudo parece porém uma ação insuficiente, esgotando-se em si ao não transcender o "território" da própria comunidade fotográfica. $\bigcirc$ processo alimentase ainda do paralelismo simbólico da descoberta do País por uma geração que se vê refletida no épico fotográfico do século anterior ${ }^{31}$; associação que certamente pouco estimulava uma revisão crítica atenta.

Novas figuras surgem nesse quadro, que poderiam ser agregadas a esta fase, embora todas elas tenham se mantido em produção contínua ate hoje. Uma delas é Pedro Vasquez, que ocupará a diretoria do Instituto Nacional de Fotografia e depois do Departamento de Fotografia, Vídeo e Novas Tecnologias, do MAM carioca ${ }^{32}$, na segunda metade da década de 1980.

Vasquez, jornalista, graduado em cinema na França, retorna ao Brasil às vésperas do incêndio do MAM carioca, local em que pensara ser possível abrigar um primeiro gabinete de fotografia ao molde das coleções de estampas.

Assume o INFoto e demonstra agilidade administrativa ao estimular projetos em andamento, em especial os programas de itinerância de exposições e as semanas nacionais de fotografia (a partir de 1982), que constituirão o locus
38. Como pesquisador mantenho uma costumeira distância de termos como "primeiro", de "porte", reflexos de julgamentos rápidos tão usuais no setor. No entanto, o conjunto de fotógrafos inclusos, em sua maior parte da coleção Gilberto Ferrez, talvez em sua primeira exibição pública em escala $\mathrm{e}$ como "fotografia brasilei ra", além da publicação de um catálogo, extenso para a época, justificam o destaque para o evento.

39. Até quase o final da década de 1980 a Funarte, através do INFoto, persistiu no esforço de organizar um colóquio da série, proposta já aventada desde 1984 na edição cubana. Seria possível apontar a ocorrência naquela geração de fotógrafos de uma certa mística mexicana, como também existira uma forte referência aos encontros de Arles.

40. Essa articulação entre organizadores locais e externos não apresentou grandes mudanças, ao contrário. Com a extinção do INFoto no início do governo Collor, desaparecia o único meio organizado de difusão da fotografia brasileira. Na esfera estadual, as raríssimas comissões de fotografia e museus não dispunham de estruturas e prestígio para tal empreendimento. $\mathrm{O}$ completo isolamento até meados da década de 1990 do circuito internacional de exposições, salvo aquelas circuladas com suporte de serviços diplomáticos, deixava o País sem uma porta de comunicação nos dois sentidos. Há pouco menos de dez anos, os pesquisadores estrangeiros não contariam com arquivos fotográficos com um mínimo de organização para atendimento, aspecto que em muito deve ter reforçado o papel da coleção pessoal de Gilberto Ferrez. Como veremos adiante, no tocante ao campo da pesquisa, apenas em momento recente 
o País contaria com um conjunto mais significativo e a cristalização de alguns pólos especia-lizados que estabeleceriam alguns pontos de comunicação internacional.

Como testemunho, posso apontar que a particularidade do desenvolvimento da fotografia no Brasil no século XX - em parte similar a toda a América Latina, com exceção do México (e Venezuela,talvez) -, no que toca ao ensino, difusão de informação, teoria e memória, é de difícil compreensão para pesquisadores europeus e norte-americanos formados em outro contexto, sem práticas nestas realidades.Apresentar esta situação a tal espectador é particularmente complexo, ainda mais em contraste com a grande intensidade da produção visual local, que parece assim como um fenômeno inexplicável (Sob esta óptica, ver o texto sobre este tema, desenvolvido pelo autor para uma platéia européia:Mendes, Ricardo. Pensando a fotografia (a memória). In: BERNARDO, Gustavo; MENDES, Ricardo. Vilém flusser no Brasil. Rio de Janeiro: Relume-Dumara, 2000).

41. Sobre a "comunidade fotográfica" de então é bom estabelecer um breve perfil. É necessário levar em conta, antes, a extensão e variedade da produção fotográfica (da foto científica à jornalística); por outro lado, a particularidade de desenvolvimento de cada um destes segmentos, seus processos históricos de formação e, enfim, a sincronicidade e permeabilidade destes campos. De qualquer forma, é possível apontar que a década de 1970 é cenário de dois movimentos:primeiro, o de relativa implantação efetiva daqueles segmentos de produção especializada no País; segundo, o de uma renovação geracional em todos os setores, ficando distante da geração anterior de encontro de uma geração e a formação de um sentimento "nacional" para a fotografia $^{33}$. Um projeto semelhante já havia sido experimentado em 1978 e 1979 por Stefania Bril (*1922 - +1992) em Campos de Jordão, todos eles filiados ao modelo de Arles - mostras, palestras e ateliês concentrados num curto espaço de tempo em cidades de pequeno porte.

Seus primeiros títulos voltados para a história da fotografia surgem em 1984, quando Vasquez lança Dom Pedro Il e a fotografia no Brasil (Index). Ao longo da década participa com textos em algumas edições de livros de imagem organizadas por Gilberto Ferrez, o que inicia uma convivência aparentemente proveitosa para ambos. De sua produção editorial, seria relevante destacar o interesse do autor por obras de difusão sobre história da fotografia, em diversos formatos, para públicos distintos, prática rara no panorama editorial local, tradicional e tragicamente marcado pelas edições de luxo ${ }^{34}$

Outra referência neste quadro, nesta geração, seria Rubens Fernandes Júnior, em São Paulo. Jornalista, ativista de grupos de memória em sua cidade natal - Rio Claro, curador da pequena mas importante galeria do Gabinete Fotográfico, na Pinacoteca do Estado (1980-1982), colecionador e crítico na imprensa, a figura de Rubens constitui-se na verdade mais como um agente de difusão de fotografia, com interesse peculiar em história da fotografia. Sua ação como historiador tem lugar mais tarde como assessor para os bancos de dados do Instituto Itaú Cultural em sua primeira fase, na administração Ernst Mange voltada para a memória da cidade de São Paulo ${ }^{35}$. Consultor do módulo século XX da base de dados do mesmo instituto, implantado na fase final daquela gestão, Rubens tem uma obra historiográfica mais tardia, na década de 1990, fora do período em questão.

Embora mais fragilizados em seus perfis perante Boris Kossoy, que em verdade ocupa o grande espaço público para o tema, ambos ainda partilham do mesmo modelo da história especializada, associado a este momento constitutivo da fotografia no Brasil na década de 1970. Esses perfis poderiam ser identificados como os de historiadores orgânicos, no sentido de produtores de obras geradas dentro do próprio processo de difusão, crítica e debate sobre fotografia no Brasil, bem como por partilharem uma produção que visa mais a organizar imagens, elaborar perfis autorais, do que propriamente à análise crítica.

Um pergunta plausível seria como medir a influência desses personagens e modelos sobre a produção de pesquisa histórica. Indo além, sobre a formação de "novos quadros", sucessores desse modelo, por exemplo.

Até meados da década de 1980 identifica-se uma produção historiográfica rarefeita, com grandes momentos, mas sempre voltada a estudos tópicos, quando muito a histórias regionais. Difícil saber agora, nesta abordagem inicial, o que destacar ${ }^{36}$. Talvez, no domínio estrito da história da fotografia de formato panorâmico, o lançamento de A fotografia no Brasil (1 985), de Gilberto Ferrez, iá mencionado.

Na década de 1980, é grande a contribuição deixada pelos livros de imagem organizados por Ferrez; embora caros e de distribuição irregular em acervos, permitiram ampliar o universo de circulação de um repertório visual em organização crescente. No tocante à produção das histórias regionais, quase sempre restritas a artigos, a maior dificuldade em outros centros urbanos 
era a completa dispersão de registros e imagens, dificultando a reconstituição de tais processos históricos. Em si, a "permanência" dessas historiografias sofre então pela não-continuidade das iniciativas, pelas edições artesanais e má distribuição, sempre distantes das capitais do Sudeste onde o interesse pelo tema era maior.

Um último ponto, finalizando o panorama sobre a primeira dentição da História da Fotografia brasileira, seria delinear o perfil das revistas especializadas. No que nos interessa, afora as revistas Iris e Novidades Fotóptica e outras iniciativas, de menor alcance regional ainda, essas publicações não serão o veículo para temas históricos, nem para o pensamento crítico mais desenvolvido.

Alguns veículos de melhor qualidade como Revista de Fotografia (1971 - ca1972) constituem-se mais como portfólios visuais, importantes iniciativas neste campo; outras, como Novidades Fotóptica, uma evolução importante ocorrida nos meados da década de 1980 a partir de um antigo catálogo de loja lançado em 1953, eram mais informativas e garantiam maior espaço à crítica. No entanto, o perfil do público leitor era evidentemente muito amplo, implicando limitações. De sua contemporânea, a revista Iris, editada a partir de 1947, é necessário apontar o titubeante perfil editorial, precário, embora tenha abrigado por momentos muito breves iniciativas relevantes da parte de alguns jornalistas. Entre eles, a crítica Stefania Bril, talvez a responsável, de forma mais contínua, pela apresentação ao grande público do pensamento de novos autores como Susan Sontag, Roland Barthes, Vilém Flusser, ou mesmo referências conhecidas como Benjamin.

Intermezzo: construção da identidade da Fotografia Brasileira

A associação proposta entre uma primeira fase da História da Fotografia brasileira e uma conjunção desse desenvolvimento ao conjunto de ações paralelas em prol de um reconhecimento da fotografia no campo cultural brasileiro merece alguns breves comentários.

É evidente que foge ao escopo deste ensaio demonstrar e justificar essa hipótese, eixo do projeto de doutorado do autor. No entanto, alguns aspectos exigem maior desenvolvimento. Entre eles, a busca do espelho externo. Diria, um espelho europeu e, em especial por ser objeto de um projeto preciso, um espelho latino-americano ${ }^{37}$.

A "primeira" mostra de porte sobre fotografia brasileira no exterior cabe a Naef e Ferrez em Nova York no ano de 197638. Dois anos depois, seria montada no México a I Mostra da fotografia latino-americana contemporânea, reunindo 173 fotógrafos do continente, sendo um terço deles brasileiros, dentro dos eventos paralelos ao / Colóquio latino-americano de fotografia. Na Europa, Erika Billeter organiza em 1981 na cidade de Zurique a mostra Fotografie Lateinamerika.

Esses primeiros movimentos de circulação internacional são até os anos iniciais da década de 1980 aparentemente desarticulados. $\bigcirc$ esforço dos organizadores mexicanos da série de colóquios é talvez a proposição mais clara, no qual vários agentes brasileiros se espelharam por alguns anos. Nesse particular, marcada pela presença do migrante. Agora a marca parece ser os novos elementos de classe média, com (ou em busca paralela) de formação universitária. Note-se que alguns nomes - muitas vezes em atuação dupla como fotógrafos e agentes especializados em outros segmentos, como jornalismo escrito,crítica,organização de eventos - terão presença contínua a partir da década de 1970 nas diversas ações visando à difusão da fotografia, à crítica e ao ensino, mantendo boa parte deles forte proximidade com o setor do fotojornalismo. Este aspecto é fundamental, pois quando tais agentes falam em Fotografia falam a partir deste locus. O efervescente panorama ao final da década de 1970 permitiu atrair muitos profissionais e amadores e outros interessados mais próximos da fotografia publicitária ou "experimental”, no entanto esta presença foi por muitos anos irregular. Apenas na década de 1990 o panorama geral iria se alterar drasticamente; a Fotografia seria agora vista de forma mais ampla, sua inserção se transformará de forma radical, mas este aspecto foge ao escopo deste ensaio.

42. Organizada por Stefania Bril e Luce-Marie Albiges, o evento teria público de 5 mil pessoas por dia, tendo percorrido por dois anos a Europa. Estes dados são interessantes, mas integram um mesmo território pantanoso. Todos estes eventos parecem permanecer num limbo terrível entre ficção e realidade. Os catálogos produzidos, muitas vezes maiores e extensos aparentemente do que o usual no Brasil,têm circulação restrita no País, quando muito.São peças raras em acervos públicos e desconhecidos por muitos pesquisadores, em especial os ingressantes no setor nos últimos dez anos. 
43. É possível estabelecer uma lista de eventos internacionais similares que tiveram menos visibilidade no Brasil,como:Horizonte 82: America Latina (Berlim, 1982), Photoamerica'84: obiettivi sull'America Latina (Milão, 1984), Corpo \& alma (Paris, 1984,Mois de la Photo), The City of Sao Paulo captured by 23 photographers (Washington, 1986), entre vários outros.

44. Evitando estabelecer uma longa lista, ver ainda a série Semana Nacional de Fotografia: 1982 - Rio de Janeiro, 1983 - Brasília, 1984 - Fortaleza, 1985 Belém, 1986 - Curitiba, 1987 - Ouro Preto, 1988 Rio de Janeiro. Neste caso, a comunidade atingida é, diferentemente das mostras mais acessíveis a um grande público, diretamente envolvida em fotografia ou em busca de inserção. Reforçam-se aqui os laços parentais;cria-se até mesmo um público comum às várias edições de evento, formado pelos organizadores, pelos fotógrafos participantes de mostras, debates e oficinas, que têm assim uma oportunidade de encontro frente a frente, de contato pessoal. Este aspecto é vital num país em que, salvo a ação da Funarte, a circulação de informações, obras e pessoas (no segmento da fotografia) é muito restrita até o final da década de 1990.

45. Uma análise efetiva mereceria levar em conta o ambiente cultural do período, do qual este processo do segmento fotográfico era um co-participante de aparente relevância. Como lembrete apenas, é bom mencionar que o período presidencial de João Baptista Figueiredo (19791985) cobre em sua totalidade o período.A propósito, Bye-bye Brazil, longametragem de Carlos Diegues, foi lançado em 1979. não só a Funarte mas fotógrafos dedicados à difusão da fotografia, no caso de São Paulo, procurariam aproximação anos mais tarde ${ }^{39}$.

E preciso apontar o esforço recíproco de sintonia entre organizadores locais e externos, que na falta de outras pontes, sem estabelecer nisso um julgamento de valor, concentraram a interlocução em alguns poucos agentes. Dentre eles, a Funarte, através de Angela Magalhães, e críticos da imprensa diária como Stefania Bril e pesquisadores como Pedro Vasquez. Essa concentração pode ter motivado uma reiteração de leituras sobre a produção brasileira, além da recorrência a um conjunto determinado de fotógrafos e críticos ${ }^{40}$.

As mostras internacionais mantêm aparentemente esses pontos de contato, com maior intensidade ao longo da década, e um interesse interno, realimentando a difusão local de notícias sobre as mesmas e a avaliação da "importância" dos eventos. Em 1981, ocorre o segundo colóquio no México, em que a coletiva Hecho en Latinoamerica gera maior impacto na comunidade fotográfica brasileira, ansiosa em participar ${ }^{41}$.

Dois anos depois, a mostra Brésil des Bresiliens ${ }^{42}$, no Pompidou, em Paris toma conta do noticiário brasileiro especializado. Essa sucessão de eventos, evitando estabelecer aqui uma lista extensa, seria completada por outras mostras organizadas por Pedro Vasquez, já como diretor do Departamento de Fotografia, Vídeo e Novas Tecnologias, do MAM carioca ${ }^{43}$. Na mesma época, já fugindo deste primeiro ciclo explosivo da metade inicial da década, uma das revistas francesas de fotografia com maior penetração na comunidade fotográfica brasileira - ZOOM, lança em 1986 seu dossiê, em dois volumes, dedicado ao Brasil.

A década de 1980 é o palco desta busca de exposição da produção nacional, de visibilidade. Quais as conseqüências efetivas do ponto de vista de imagem e auto-imagem da fotografia brasileira? No exterior, é difícil identificar no momento seus resultados. No campo interno, o reforço à identidade (em construção) é muito forte.

Há um significativo paralelo (de sucesso e de busca de identidade) nas mostras nacionais propostas pelo Núcleo de Fotografia da Funarte, coletivas que procuram atrair o maior número de participantes, em editais que "circulam pelo país". Os temas são sugestivos como Nossa gente (1979) e Classe Média Brasileira (1980), além de explorar o sabor de uma época como Carnaval de Malta (1980) e Visita do Papa ao Brasil (1980). Em paralelo, a mesma entidade expõe mostras geradas externamente como Revolução de 30, organizada pelo CPDOC/FGV em 1980, e dois anos depois, também coordenado pelo mesmo órgão - Revolução de 32: a fotografia e a política.

Embora com menor visibilidade, além da promoção das semanas nacionais de fotografia (seguindo o modelo de Arles), a Funarte começa a gerar mostras regionais similares as anteriores. Entre elas, Foto Centro-oeste (1983) em Brasília, I FotoSul (1983) em Curitiba e I Fotonordeste (1984), entre outras, já sob coordenação do INFoto - Instituto Nacional de Fotografia, que sucede ao Núcleo de Fotografia da Funarte. Em paralelo, o programa de itinerância ganha forma: Nossa gente circula, por exemplo, em Aracaju (1979) e Brasília (1983). As mostras regionais procuram seguir o mesmo procedimento, veja a remontagem de I Fotosul, em Fortaleza, durante a III Semana Nacional de Fotografia (1984).

Ainda que essa circulação não seja tão articulada e regular em função de restrições orçamentárias, a intensidade de ações entre 1978 e 1983 leva 
provavelmente a um permanente reforço de imagem perante o público interessado em fotografia, além da própria comunidade fotográfica ${ }^{44}$.

Como resumo desse encadeamento de eventos, podemos apontar algumas diretrizes: parece ocorrer um descobrimento do Brasil (pela fotografia), mas antes de tudo um auto-reconhecimento da própria comunidade fotográfica, espelhando-se por um lado num passado documentarista e, por outro, procurando ser veículo de um olhar contemporâneo ${ }^{45}$.

papel do Estado através da Funarte, sem fazer aqui um juízo crítico, é relevante como vetor para esta consciência nacional, mais precisamente por permitir surgir um sentimento nacional para o segmento da fotografia no Brasil. Ainda que suas ações, muito fragmentárias e sem recursos, visassem apenas a estabelecer canais de comunicações, os resultados foram muito além das expectativas.

Uma nova história: segunda dentição

Qual seria o intervalo de tempo adequado para medir resultados no campo da cultura? Do ponto de vista do Estado brasileiro ao final do século XX, políticas culturais quase sempre se traduziram em eventos de cunho imediatista. No quadro traçado entre 1975 e 1985, o encontro e interação de diferentes vetores pode ter detonado um processo pouco claro, mas que, por si, se move. E talvez por isso mesmo a partir de meados da década de 1980, numa aparente transição de tendências o campo do pensamento em fotografia apresente um momento de repouso ${ }^{46}$. Mas algo sucede, como veremos.

mercado editorial, voltado para ensaios críticos, vai muito lentamente ganhando fôlego no período de 1985 a 1995. Resultado de ações isoladas, introduz por um lado alguns textos clássicos - Roland Barthes (1984, Nova Fronteira) - Câmara clara, Vilém Flusser (1985, Hucitec) - Filosofia da Caixa Preta, Susan Sontag (1981, Arbor) - Sobre a fotografia ${ }^{47}$. Em parte, reflete um crescente interesse por estudos do estatuto lingüístico da fotografia, de ênfase semiótica ${ }^{48}$.

Ao mesmo tempo alguns ensaístas de origens diversas editam, de forma não regular, reunindo material esparso. Entre eles, a crítica Stefania Bril (1987, Prêmio Editorial) com sua antologia sobre fotografia internacional - Notas: vinte e nove mestres da fotografia, os jornalistas e professores Luiz Humberto (1983, Funarte) - Fotografia: Universos e arrabaldes e Ivan Lima (1988, Espaço \& Tempo) - A fotografia é a sua linguagem, e Pedro Vasquez (1986, L\&PM) Fotografia: reflexos e reflexões. Quase sempre, esses ensaios revelam sua origem na imprensa, resultando em conjuntos ligeiros mais voltados ao grande público e não abordagens severas de tendências teóricas. No entanto, seus autores falam a partir de um ponto de vista mais próximo da prática da fotografia, em especial, do fotojornalismo.

Boris Kossoy dá no mesmo período os primeiros passos para orientar sua produção para o campo da teoria da história, analisando com destaque o uso da fonte iconográfica em pesquisa em história, avaliando o estatuto do documento fotográfico (1 980, Secretaria da Indústria, Comércio e Tecnologia de São Paulo) - A fotografia como fonte histórica: Introdução à pesquisa e interpretação das imagens do passado. Quase dez anos depois, lança Fotografia e história
46.A intensidade das questões levantadas sobre o campo da fotografia, em especial no tocante à memória, até meados da década de 1980 parece ter sido de tal monta, refletindo alta parcela de projeção e investimento por parte de seus participantes, que a observação do momento seguinte pode revelar algo de desapontador, resultado de gestos inconclusos. Realizouse menos do que o esperado.Algumas instituições perderam-se no tempo, a exemplo dos MIS carioca e paulistano. Acervos importantes permaneceram relegados - penso no Arquivo de Negativos, de SMC ou nos arquivos de documentação ferroviária até hoje pouco explorados e nada acessíveis a pesquisadores especializados em fotografia. No entanto, em termos pessoais, acredito que a demanda feita por aquela geração previa um cronograma irreal, desconhecia a natureza das instituições e enfrentou a perda de um elemento importante com o desmantelamento do INFoto.

47. Walter Benjamin, que constitui outra das referências de longa data no pequeno debate sobre fotografia no Brasil, foi no período objeto de um esforco editorial que gerou uma ampla oferta. Se o ensaio clássico sobre o estatuto da obra de arte na era da reprodução gráfica é desde a década de 1970 amplamente citado, ainda que impropriamente no campo da fotografia sem o apuro crítico necessário, seu outro ensaio, mais específico, Pequena bistória da fotografia não parece ter encontrado o mesmo eco embora tenha sido editado quase simultaneamente em duas antologias (Fernandes, Florestan (coord.) ; Kothe,Flavio R. (org). Walter Benjamin: sociologia. São Paulo: Ática, 1985; Magia e técnica, arte e política. 
São Paulo: Brasiliense, 1985, esta com três edições até 1987).

*** Em função da quantidade de menções a livros a partir deste ponto, adotou-se a referência resumida no corpo do texto.

48. Um bom exemplo são os ensaios apresentados no II Congresso Brasileiro de Semiótica, realizado em São Paulo, de 2 a 6.10.1985, que reunia várias comunicações sobre fotografia, publicados em Semiótica da comunicação e outras ciências (São Paulo: Educ/ Fapesp, 1987).

49. O mundo da rua representa importante manifestação da cosmologia fotográfica nacional. Embora sem ligação direta, já na primeira década do século XX com a presença das primeiras revistas ilustradas ocorre um deslumbramento com a vida social nas ruas. Décadas depois, já se apresentando como gênero fotografia de rua, essa produção teria uma grande expansão, embora até hoje sem merecer uma avaliação.

50. Sem estabelecer um juízo sobre a obra, dentre os alunos destaca-se o fotógrafo Emídio Luisi com uma longa produção de ensaios sobre a cidade de São Paulo, enfatizando a migração, que constituirá para um grande público a tradução de uma antropologia visual.

51. No segmento das exposições é contínua e paralela a difusão da obra fotográfica de Verger. Já em 1978 no MASP é montada $D a$ senzala ao sobrado:arquitetura brasileira na Nigéria e na República de Benin com pesquisa de Manuela e Marianno Carneiro da Cunha. Quase dois anos depois, em 1980, o mesmo museu recebe a exposição Verger, Cravo, com obras suas e de Mário Cravo Neto. Consultar as bases de dados em FotoPlus, já
(1989, Ática), em que o tema levantado pela primeira obra surge de forma mais condensada e focada no estatuto do documento.

No campo teórico a contribuição de maior permanência e difusão será a edição da dissertação de mestrado de Arlindo Machado (* 1949), apresentada na PUC-SP em 1983, que ganha forma um ano depois - A ilusão especular: introdução à fotografia (1983, Brasiliense/Funarte). É, certamente, a melhor apreciação em conjunto de abordagens teóricas conhecidas, mas apresentada de forma sistematizada. Machado atuaria a partir de então, por período breve, como crítico da imprensa diária, voltando porém a concentrar-se nos anos seguintes em sua carreira acadêmica na ECA-USP e PUC-SP.

Uma rápida consulta a bibliografias universitárias, já na transição para a década de 1990, permite identificar alguns autores que encontram uma boa recepção a seus trabalhos e, o que importa, inauguram um debate sobre a imagem (fotografia e filme, mais tarde, marcantemente o vídeo) no campo dos estudos sociais, e gradativamente ganhando espaço no da antropologia. Entre os primeiros títulos nessa direção incluem-se Escravos brasileiros do século XIX na fotografia de Christiano Jr, organizado por Mauricio Lissovsky e Paulo César de Azevedo (1988, Ex Libris), e Retratos de família: leitura da fotografia histórica, de Miriam Moreira Leite (1993, Edusp).

Ainda no segmento das ciências sociais seria importante destacar a presença desde a década de 1970 de um permanente interesse, ainda que informe e algo improvisado pela "antropologia visual". Antes mesmo que a produção acadêmica indicasse uma quinada para o estudo do cotidiano urbano, fotógrafos improvisaram uma prática nessa direção49. Editado já em 1973 (EPU/Edusp), o agora "clássico" A antropologia visual: a fotografia como método de pesquisa, de John Collier Jr, recebeu o tratamento de "bíblia" por duas décadas, embora aparentemente pouco discutido. Quase quinze anos depois, em 1987, surge outro tífulo nesse campo, aparentemente uma publicação, de alcance restrito Caderno de textos: antropologia visual (1987, Museu do Índio), com ensaio de Etienne Samain.

Se a circulação de ensaios críticos voltados para antropologia visual parece reduzida, é necessário apontar a quantidade crescente de mostras sobre o tema. Já em 1982, o italiano Sandro Spini realiza no MIS paulistano o primeiro curso sobre fotoetnografia, que teria em seu grupo de alunos vários praticantes "selvagens" desse gênero 50 , sendo montada em paralelo a mostra Antropologia visual: a fotografia (MIS, 23.3 a 11.4.1982) com ensaios de autores italianos: Ferdinando Scianna, Francesco Faeta, Francesco Spada, Franco Pinna, Lello Mazzacane, Marina Malabotti, Mario Cresci, Salvatore Piermarini e Sandro Spini.

Deve ser vista ainda como uma contribuição a esse campo a difusão da obra de Pierre Verger (* 1902 - +1996). O lançamento em 1980 (Corrupio) do livro Retratos da Bahia: 1946 a 1952 marca o "descobrimento" pela fotografia brasileira daquele que ganharia estatuto de ícone. Após esse encantador panorama de Salvador, a editora Corrupio, criada por Arlete Soares e Cida Nóbrega com o propósito de divulgação da produção de Verger, lança em co-edição do Círculo do Livro (1982) a obra que marca a apresentação a um público mais amplo das pesquisas desenvolvidas pelo antropólogo: Orixás: os deuses iorubás na África e no Novo Mundo. No mesmo ano, a editora Corrupio editaria 50 anos de fotografia ${ }^{51}$. 
A produção crítica sobre arte e fotografia não é tão fácil de identificar ou agrupar. Com certeza, em São Paulo, seria possível apontar a presença de Annateresa Fabris (* 1947), no Departamento de Artes Plásticas da ECA-USP. Fabris mantém na pós-graduação desde o início da década cursos regulares sobre arte e fotografia, em especial durante o século XIX. Esses cursos atrairiam assim uma leva de pesquisadores, ao constituírem uma oportunidade única de estudo especializado na esfera da Universidade de São Paulo. Em 1990, Fabris realizaria um seminário com vários desses pesquisadores, que resultou na antologia Fotografia: usos e funções no século XIX (1991, Edusp), reunindo um conjunto de ensaios que tratam a presença da fotografia no período de modo atento à circulação e percepção social ${ }^{52}$.

Seria importante mencionar que datam do período os primeiros trabalhos de Paulo Herkenhoff ( * 1949), cuja presença será mais visível na segunda metade da década de 1990. Seu ensaio, editado em 1983 - Fotografia: o automático e o longo processo de modernização - seria um dos primeiros a abordar reflexos de modernização na fotografia brasileira da metade do século XX53.

Este breve panorama editorial da década de 1980 é apenas uma introdução ao ponto que nos interessa: a alteração de modelo de desenvolvimento da história da fotografia e a sua inserção em contexto novo. Seria importante apenas lembrar que essa produção crítica teria por fundo um conjunto maior de publicações, voltado para públicos não especializados, constituído pelos livros fotográficos propriamente. Edições estimuladas pela introdução das primeiras leis de incentivo à cultura baseadas em renúncia fiscal, esses livros permitiram a circulação nacional de imagens restritas até então a arquivos públicos sem acesso organizado ou a coleções pessoais.

Com certeza, essa vertente da produção brasileira mereceria uma análise cuidadosa, pois a diversidade de linhas adotadas e o tratamento heterogêneo do material visual provavelmente nivelaram por baixo, numa expressão coloquial, o universo de imagens veiculadas. Além do fato do formato livro de arte, com tiragens caras e de circulação completamente anárquica, para dizer o mínimo, ter reduzido o leque do público em potencial ${ }^{54}$.

Agora, delineado o contexto imediato da década de 1980, é possível traçar uma hipótese para compreender a fase que começa a ganhar forma. $\bigcirc$ campo de produção da história e crítica em fotografia no Brasil expande-se. Aqui apresentaremos apenas tendências. O universo a ser trabalhado é não só extenso, mas marcado intensamente pela dispersão de fontes.

Se na década anterior era possível manter-se ao redor desta dupla de agentes, várias vezes fundidos numa só pessoa, o historiador especializado e o crítico, o modelo em formação é outro. A tendência é a diversificação de saberes, especialização porém em busca, na medida do possível, de interação. Essa diversificação, aglutinada em diferentes centros de produção, terá lugar num horizonte dominado pela dispersão, mantendo-se quando muito com relativo grau de difusão na esfera universitária.

segmento da pesquisa acadêmica, através dos programas de pósgraduação, irá gradualmente consolidando pólos com alguma volumetria de trabalhos a partir de meados da década de $1990^{55}$.

Em São Paulo destacam-se a USP, em vários institutos, a UNICAMP, em especial no Departamento de Multimeios do Instituto de Arte, e a PUC-SP, no programa de Comunicação e Semiótica. No caso da Universidade de São Paulo, mencionadas, para obter uma relação de montagens na capital paulista.

52. Iniciativa assemelhada seria realizada por Etienne Samain, reunindo orientandos e pesquisadores reconhecidos, não só da comunidade Unicamp, ao editar: $O$ fotográfico (São Paulo: Hucitec/CNPq, 1998)

53. Herkenhoff, Paulo. Fotografia:o automático e o longo processo de modernização. In: Tolipan, Sergio et alli. Sete ensaios sobre o modernismo. Rio de Janeiro: Funarte, 1983

54.Uma primeira listagem dessa produção editorial incentivada, não restrita à fotografia, é analisada por Cacilda Teixeira da Costa, em: Livros de arte no Brasil: edições patrocinadas. São Paulo: Itaú Cultural, 2000 .

55. Tomamos como referência um levantamento sobre teses e dissertações disponível no site FotoPlus, atingindo um total de 191 menções (em janeiro de 2003; em julho, 246 registros).Desse total, um porcentual mínimo, inferior a 10 por cento, refere-se a entradas duplas: teses defendidas e teses editadas. Ainda assim, do total de 191 referências, cerca de 97 foram produzidas em São Paulo (60 na USP, 19 na PUC), $31 \mathrm{em}$ Campinas, 38 no Rio de Janeiro e Niterói.A atualização deste levantamento é muito lenta e algo precária, no entanto acreditamos que possa ser tomado como indicador de tendências. A cobertura carioca foi aprimorada em 2002 com o projeto em desenvolvimento pelo autor no Rio de Janeiro, mas ainda apresenta falhas graves de cobertura em relação a centros importantes como a UFFHistória. É possível ainda indicar que este total de 191 referências inclui 151 
mestrados (57 em São Paulo;31 no Rio de Janeiro, 24 em Campinas) e 39 doutorados (28 em São Paulo; 6 no Rio de Janeiro, 1 em Campinas). Do ponto de vista de datas de defesas o panorama é inesperado (aqui listadas sem distinção entre mestrados e doutorados). A tese mais antiga referese a aplicações técnicas, projeto sobre aerofotogrametria apresentado em 1940 em concurso de cátedra (RJ). Apenas em 1971 encontramos nova menção:um mestrado no INPE (SP) sobre fotografia de satélites. No ano seguinte, registra-se a primeira referência no campo de Humanas, uma análise da fotonovela, mestrado desenvolvido na FFLCH-USP (Ciências Sociais), por Angeluccia Habert. Em 1978, como mencionado ao longo do texto, após outras três referências, encontra-se a primeira tese (dissertação de mestrado) sobre história da fotografia desenvolvida por Kossoy na Escola de Sociologia e Política.

Para detalhamento dos títulos, insistimos na consulta ao site mencionado.

56. O longo período de ausência de cursos de graduação em fotografia no País, em contraste gritante com o panorama europeu e norte-americano, fez do tópico um dos mitos reorganizadores identificáveis na comunidade fotográfica. No período coberto por este ensaio a necessidade da ESCOLA era apresentada como meio para organizar o mercado, garantindo padrões de eficiência, aumentando a qualificação e conseqüentemente preços praticados.A tardia introdução, embora festejada, não teve maiores repercussões. É preciso apontar que as tentativas de regulamentação da profissão empreendidas talvez os focos mais relevantes sejam a ECA-USP, nos Departamentos de Artes Plásticas e de Jornalismo e Editoração, e a FFLCH-USP, no Departamento de História. No entanto, essas concentrações são muito relativas. No Rio de Janeiro, o pólo de maior concentração é representado pela Escola de Comunicações da UFRJ, seguido bem abaixo pela Escola de Belas Artes, da mesma universidade.

Além desses programas regulares registram-se ao final da década de 1990 alguns programas de extensão, especializações oferecidas ao nível de pós-graduação. Em 1996, na Universidade Estadual de Londrina é realizado curso de curta-duração Especialização em fotografia: o discurso fotográfico. Em São Paulo, apenas em 1998 apresenta regularidade a iniciativa do SENAC CCA - Centro de Comunicação de Artes de cursos de extensão em Fotografia tecno-científica e Fotografia e mídia, projetos que precedem o funcionamento do primeiro curso de graduação no País, oferecido pela entidade em 199956. No Rio de Janeiro, a realização na Universidade Cândido Mendes, após uma tentativa na Universidade Gama Filho, do curso de pós-graduação lato sensu, organizado por Milton Guran, Fotografia como instrumento de pesquisa nas ciências sociais, conseguiu atender a uma demanda reprimida e funcionar como pólo de aglutinação de fotógrafos e pesquisadores daquela cidade ${ }^{57}$.

A análise da produção resultante dos programas regulares de pósgraduação está por ser feita e demandará algum esforço, pois numa primeira avaliação o percentual de títulos editados é inferior a dez por cento. Além, é claro, das características usuais do mercado brasileiro, como ausência de reedições, distribuição, irregular e dificuldade de aquisição pelas bibliotecas.

É possível apontar que há um predomínio, ao menos no início da década de 1990, de projetos de pesquisa voltados para análise de abordagens filiadas à semiótica, enfocando com destaque o fotojornalismo. Nota-se um quase inexistente interesse pela fotografia publicitária e de moda, ainda que esta última tenha conquistado alguma relevância no campo do estudo da cultura de massa, com o crescente desenvolvimento do segmento acadêmico em moda.

No campo da história da fotografia detectam-se tendências regionais. No Rio de Janeiro, a produção concentra-se sobre o século XIX, conseqüência talvez do grande conjunto de instituições de memória com acervos expressivos localizadas na cidade, foco que contrasta com a quase inexistência de estudos sobre o século seguinte, tendência acompanhada pelo mercado editorial. No caso paulistano, ocorre uma intensa dispersão temática, com projetos voltados para casos específicos ao longo do século XX, muitos deles ligados à história política.

A produção acadêmica da UNICAMP é particularmente distinta. A presença de Etienne Samain ( 1938) ${ }^{58}$ - responsável por um número apreciável de orientações de recorte temático variado, ainda que o interesse pela antropologia visual seja marcante -, parece ter colaborado para a introdução regular de uma bibliografia recente de origem francesa ${ }^{59}$, No tocante à história da fotografia as ocorrências são mais regulares e focadas do que na USP, revendo temas clássicos como Militão Azevedo e Augusto Malta ${ }^{60}$.

A baixa ocorrência de projetos acadêmicos voltados para a história da fotografia em si não me parece relevante. Importa mais a diversificação temática de saberes, que em si, como exigência da própria prática de pesquisa, acaba gerando os primeiros delineamentos de histórias setoriais. $\bigcirc$ que se deve perguntar é se esse novo modelo do campo de pensamento em fotografia, 
diversificado mas disperso, tem condições de continuidade sem maiores intervenções.

Nesse aspecto, uma experiência recente tem ocorrido em particular no campo das ciências sociais: o estabelecimento de programas de pesquisas especializados, estruturados como projetos reconhecidos oficialmente, abrigados em departamentos universitários. Talvez a experiência mais antiga na área de antropologia seja o LISA - Laboratório de Imagem e Som em Antropologia (FFLCHUSP), desde 1991 com a presença de Sylvia Caiuby Novaes. Mas nos últimos anos é possível registrar várias iniciativas assemelhadas. $\mathrm{Na}$ área de antropologia visual, destacam-se: UFPE - Laboratório de Antropologia Visual, UERJ - NAl Núcleo de Antropologia e Imagem, UFF - LEV - Laboratório de Etnografia Visual, UFRGS - NAVISUAL - Núcleo de Antropologia Visual, UFSC - Laboratório de Antropologia Visual. Na área de história, destaca-se desde 1982 o LABHOI UFF - Laboratório de História Oral e Imagem. E num terreno mais extenso, seria possível incluir: UFRJ - IFCH - NAVEDOC - Núcleo Audio Visual de Documentação; UFBA - DH - Núcleo de Pesquisa e Produção em Imagem, e UFRJ - IPPUH Núcleo de Documentação Visual Urbana.

A relevância desses programas para o setor é a possibilidade de estruturação de linhas temáticas, uso de fontes de financiamento regular e programas de difusão mais sistemáticos.

O que ocorre neste segundo momento da História da Fotografia aqui proposto, além da dispersão de saberes através da expansão da pesquisa aplicada? Com certeza, uma perda de importância da figura do historiador de fotografia especializado, perda por uma insuficiência em atender às novas demandas ${ }^{61}$. E perda também por falta de renovação de modelos no campo da memória fotográfica como um todo. Neste particular é preciso apontar que as condições iniciais de expansão dos programas de pós-graduação geraram uma marca particular sobre a produção imediata, expressa por trabalhos em que se contrasta a informada bibliografia especializada internacional com a rarefeita historiografia local, insuficiente (e inacessível em parte), trabalhos muitas vezes desinformados da pesquisa de campo mais recente.

Esses trabalhos refletem assim a parca bibliografia nacional e o fato cruel das bibliotecas universitárias desaparelhadas neste tópico, bem como ficaram sujeitos em sua realização ao desenvolvimento lento e inadequado dos arquivos fotográficos nacionais no tocante à renovação de serviços e instalações.

Alguns exemplos bem próximos, neste último tópico, merecem ser avaliados. Apenas em meados da década de 1990 a Biblioteca Nacional consegue estabelecer o Profoto, programa de tratamento da coleção Theresa Cristina Maria, a coleção do imperador, garantindo o acesso mais amplo e a conservação da coleção.

A grande novidade no segmento foi o surgimento de novos participantes no segmento de instituições de memória, novas entidades de caráter privado, cuja originalidade principal está na forma de captação de recursos. $\bigcirc$ exemplo mais evidente é o Instituto Moreira Salles, que a partir de 1995 passa a formar a que será em menos de três anos a maior coleção fotográfica, fora da esfera do Estadob2. O instituto, reorganizado como instrumento de captação de recursos por renúncia fiscal, caracteriza-se até o momento como vetor de aglutinação de acervo sobre fotografia brasileira, de caráter documental, até a década de 1950. Não apresenta um programa formal de atuação para o setor, nem uma política clara no tocante à nas décadas de 1970 e 1980, que funcionavam como um vetor para agregação dos participantes, não tiveram resultado concreto. Considerando que apenas no final de 2002 graduou-se a primeira turma da Faculdade SENAC, há um largo período de espera para a avaliação dos resultados. Os cursos de extensão lato sensu aparentemente têm funcionado mais como cursos de especialização técnica. No quadro mais recente, considerando-se a cidade de São Paulo, as ofertas de cursos de graduação encontram novas configurações. Desde 1998 a ESPM - Escola Superior de Publicidade e Marketing - oferece cursos de formação de quatro semestres, sem reconhecimento como curso superior (prática não muito diversa da realizada em menor escala pela Escola Panamericana de Arte). No entanto, nos dois últimos anos, com a aprovação dos cursos superiores de curta duração, denominados cursos seqüenciais, surgem opções através do Instituto Politécnico, da Universidade Estácio de Sá, no Rio de Janeiro, e em São Paulo, cursos oferecidos pela UNIP, orientado para fotografia digital, Universidade Ibirapuera, orientado para fotografia de moda e publicitária, e FMU, mais genérico: Tecnologia da produção de fotografia, cinema, rádio, tv e vídeo. Essas ocorrências no mercado de ensino superior indicam provavelmente um período, a médio prazo, de ajustes, certamente com prejuízo para os interessados: os alunos. Note-se que há uma tendência de mixagem entre fotografia tradicional e as vertentes de veiculação 
digital, via Internet, sem qualquer definição clara de formato de curso.

57. É surpreendente o sucesso da primeira edição em 2001, aparentemente repetido em 2002 . O formato do curso, composto por disciplinas e seminários, que permitem inscrições específicas para cada módulo, bem como a estruturação de cada disciplina, que além de um professor responsável articula várias palestras de especialistas convidados, garantiu um mix de temas e pessoas de grande interesse. Com certeza, a figura e a carreira de Milton Guran são abonadores do projeto, embora a médio prazo as novas edições exijam uma reorientação do programa.

58. É necessário apontar que Samain é o autor do primeiro ensaio abrangente que traça um perfil do pensamento teórico e historiográfico sobre fotografia no Brasil: A "caverna obscura": topografias da fotografia. IMAGENS, Unicamp, v.1, p. 50-61, abr. 1994.

59. Essa tendência encontrou resposta no setor editorial local através da editora Papirus na década de 1990, responsável pela edição de obras de Philippe Dubois, Jacques Aumont, Jean-Marie Schaeffer, entre outros. Nos últimos anos, a editora incluiu entre seus lançamentos obras de Arlindo Machado, Miriam Moreira Leite, Fernando de Tacca e Maria Helena Capelato.

60. A produção acadêmica na PUC-SP, através do programa em Comunicação e Semiótica, afora a abordagem da fotografia inserida num contexto mais amplo das mídias técnicas, muitas vezes em projetos que não privilegiam em si determinado suporte técnico, não foi objeto de uma pros- difusão através de mostras e publicações. Sob esse aspecto, como a formação de acervo mostrou-se prioritária sobre outras atividades internas de trabalho, o acesso público é praticamente restrito, dificultado pela ausência de qualquer instrumento de pesquisa, além do ônus de custos cobrados por hora de pesquisa, procedimento que a entidade foi "obrigada" a implantar diante da demanda reprimida.

A atuação da entidade tem sido criticada ante a inexistência de um plano de tratamento e disponibilização de acervo. Em especial, a atuação institucional de modo pouco transparente associada à magnitude do acervo já reunido, conjunto que inclui a coleção Gilberto Ferrez e alguns dos arquivos pessoais de fotógrafos eminentes da primeira metade do século XX, inviabilizam a produção mesmo de projetos de pesquisas e editoriais sobre momentos e autores significativos do período por parte do público externo.

Os museus da imagem e do som, tanto no Rio como em São Paulo, não conseguiram definir um espaço próprio e muito menos tratar e disponibilizar seus acervos até o momento. No caso carioca, projetos de renovação garantiram visibilidade para o acervo da Biblioteca Nacional e, em especial, o Arquivo Nacional, que finalizou em 2002 uma completa reforma das instalações. Certamente, essa entidade em conjunto com o CPDOC/FGV constituem-se como as fontes mais relevantes para a pesquisa iconográfica no campo do Estado brasileiro.

No caso paulistano, a única renovação marcante, afora alguns acervos importantes já estabilizados como o IEB-USP, tem lugar no Museu Paulista-USP, a partir da gestão do prof. Dr.Ulpiano Menezes, que estabelece as primeiras ações para ampliação do acervo fotográfico e seu tratamento. Na verdade, a atual coleção do museu, que agregou a partir de 1993 as coleções dos fotógrafos Militão Augusto de Azevedo e Dana Merrill (sobre a Estrada de Ferro MadeiraMamoré) e as coleções de retratos dos colecionadores Carlos Eugênio Marcondes de Moura e Orôncio Vaz Arruda, constitui o mais importante repertório histórico fotográfico existente na cidade. Preservada, catalogada e disponível ao público em sua integridade, é a coleção mais relevante no setor na última década na cidade de São Paulo.

No campo da fotografia como meio de expressão os avanços são igualmente recentes. Além da coleção - relativamente pouco explorada e circulada do MAM carioca, as iniciativas em São Paulo realizaram-se em lugares bem distintos. A mais antiga, no MASP, através da coleção Pirelli-MASP, a partir de 1991, constituindo um acervo de referência sobre fotografia brasileira, curiosamente abrigado num museu de arte de recorte temporal bem diverso. É caso distinto, e particularmente promissor, o da coleção organizada nos últimos quatro a cinco anos no MAM paulistano, de modo quase informal, com forte presença curatorial de Tadeu Chiarelli, reunindo uma produção mais recente e em maior diálogo com o panorama contemporâneo de artes visuais ${ }^{63}$.

\section{Como avançar?}

A questão que se apresenta à produção da história da fotografia no contexto delineado é como prosseguir. A ausência de novos especialistas com 
permanência a médio prazo, gerando uma produção regular, e a dificuldade de intercâmbio de informações parecem dificultar esta visão em perspectiva e integrativa de uma historiografia para o setor. Exceto pela presença dos programas de pesquisas em ciências sociais, não existe uma ação inovadora, um modelo novo.

As conseqüências imediatas dessa situação vão além das dificuldades para a formação de pesquisadores e manutenção de uma produção regular em suas diversas especialidades no campo da fotografia, mas incidem também na difusão perante o grande público sujeito assim à reiteração de uma história, agora sim, oficialesca ${ }^{64}$.

termo reiterativo é adequado para descrever a situação. Na falta de produção crítica historiográfica, uma imagem histórica vai se replicando. Vejase o exemplo dos panoramas sobre a expansão da fotografia no Brasil no século XIX visualizados sempre a partir do grande centro: a Corte. Em nenhum caso merece destaque o fenômeno expressivo (e de "longa" duração) dos fotógrafos itinerantes - profissionais que desde o primeiro momento embrenharam-se pelo território brasileiro "ensinando e descobrindo" o que era, como se praticava a fotografia. Curioso foco este do centro, quando lembramos que em meados do século XIX, embora em relativo declínio, cidades como Salvador e Recife constituíssem mercados para a nova profissão. Nem por isso essas leituras históricas dão conta de modo equilibrado. Escritas a partir do centro, excluem os fatos e os leitores que não se situem a partir dele.

Outro aspecto reiterativo é como a produção historiográfica contemporânea repete a situação isolacionista da fotografia distante das demais mídias visuais na sua investigação.

Uma historiografia que não se pensa, não reflete sobre sua matriz de agentes - historiadores instituições de memória políticas públicas - está sujeita a perder função como área de pensamento.

Essa decisão programática marcaria assim a proposição de uma terceira fase da História da Fotografia brasileira. Qual o caminho? Possivelmente a abordagem integrativa de focos, mas com autonomia necessária, estabelecendo o diálogo com outras imagens técnicas, uma conversação entre experiências históricas distintas. "This is why we need a history of picturemaking that confronts alls pictures with hard questions about their relationships to worldmaking" (CHIARENZA, 1980).

\section{REFERÊNCIAS}

Estão relacionadas apenas as obras de maior "centralidade" e abrangência.

Além das indicações presentes nas notas, veja a base bibliográfica sobre fotografia no Brasil no site: $<$ http://www.fotoplus.com/database>

BARTHES, Roland. Câmara clara. Rio de Janeiro: Nova Fronteira, 1984.

CHIARENZA, Carl. Notes toward an integrated history of picturemaking. In: READING into photography: selected essays: 1959-1980. Albuquerque: University of New Mexico Press, 1982. pecção adequada, mais extensiva. Dessa forma, não é enfocada nessa primeira avaliação.

61. É necessária uma resposta à pergunta inevitável:qual a produção recente dos historiadores mencionados na primeira fase? Kossoy permanece no campo internacional como a personalidade de maior presença em seminários e antologias especializadas. No campo interno, sua produção recente no mercado editorial mantém por um lado a abordagem do estatuto da fotografia na pesquisa histórica - Realidades e ficções na trama fotográfica (Cotia: Ateliê Editorial, 1999) e, por outro, a elaboração, a partir de sua tese de livre-docência, da obra de referência Dicionário bistórico-fotográfico brasileiro: fotógrafos e ofício da fotografia no Brasil (São Paulo: IMS, 2002). Pedro Vasquez conserva sua regular produção de obras de cunho histórico, não destacando-se pesquisas de maior fundo: Fotógrafos alemães no Brasil do século XIX (São Paulo: Metalivros, 2000) e Postaes do Brazil: 18931930 (São Paulo: Metalivros, 2002). Rubens Fernandes Junior cristalizou a partir do final da década de 1990 uma produção mais efetiva em história da fotografia a partir de textos para grandes mostras. A primeira (e talvez mais importante), a coletiva Brasilianische Fotografie: 1946-1998 Labirintos e identidades, realizada na Alemanha em 1999, sob sua curadoria. Em seguida, realiza a mostra O século XIX na fotografia brasileira, em curadoria conjunta com Pedro Correa do Lago, em 2000 na cidade de Brasília, $\mathrm{e}$, finalmente, o segmento sobre fotografia da exposição Brasil 1920-1950:da antropofagia a Brasília, realizada em 2000 na Espanha, sob a coordena- 
ção de Jorge Schwartz, que atuou em colaboração com Rubens Fernandes. Os três eventos seguiram programas de itinerância nos anos seguintes.

62. Um exemplo assemelhado, mas com um recorte mais definido, é o da FPHESP - Fundação do Patrimônio Histórico da Energia de São Paulo. A entidade foi criada em 1997 como parte do processo de privatização das estatais do setor energético do Estado de São Paulo, cujas concessionárias passaram a responder por sua manutenção. $\mathrm{O}$ acervo iconográfico inclui coleções significativas como a documentação da Light São Paulo, responsável a partir de 1899 pelos serviços de transporte por bonde elétrico e sistema de geração e distribuição de energia elétrica na capital e região. Os trabalhos desenvolvidos em organização e tratamento de acervo, implantação de museus de energia no interior, manutenção de usinas históricas e programa editorial merecem atenção. No entanto, o nãocumprimento do plano de metas para atingir a autonomia financeira no prazo estabelecido de cinco anos tem gerado uma crise cujas conseqüências podem ser devastadoras.

63. Sobre esta última,veja o texto: Mendes, Ricardo. Para que servem as coleções (fotográficas)? In: $F_{O}-$ tografias no acervo do Museu de Arte Moderna de São Paulo. São Paulo: MAM, 2002. Merece registro o fato da inexistência no Brasil, afora o conjunto doado por Dom Pedro II, de coleções expressivas sobre fotografia internacional, sob qualquer recorte - temático, temporal ou geográfico.

64. Ou, num tom irônico, sujeito a um retrato mínimo cada vez mais, desse campo do conhecimento.
COSTA, Cacilda Teixeira da.Livros de arte no Brasil:edições patrocinadas. São Paulo: Itaú Cultural, 2000.

DEIRÓ, Eunápio. A arte I. Kosmos, Rio de Janeiro, v. 1, n. 11, nov. 1904.

FERNANDES Junior, Rubens. Brasilianische Fotografie: 1946-1998: Labirintos e identidades. Wolfsburg: Kunstmuseum Wolfsburg, 1999. (2003, Cosac \& Naify)

FERNANDES Junior, Rubens; LAGO, Pedro Correa do. O século XIX na fotografia brasileira. São Paulo: FAAP / Francisco Alves, 2000.

FERREZ, Gilberto. A fotografia no Brasil e um dos seus mais dedicados servidores: Marc Ferrez. Revista do Patrimônio Histórico e Artístico Nacional, Rio de Janeiro, v. 10, p. 169-304, 1946.

FERREZ, Gilberto. A fotografia no Brasil: 1840-1900. Rio de Janeiro: Funarte/Pró-Memória, 1985.

FERREZ, Gilberto; NAEF,Weston. Pioneer photographers of Brazil: 1840-1920. Nova York: Center for Inter-american Relations, 1976. (catálogo de exposição)

FLUSSER, Vilém. Filosofia da caixa preta. São Paulo: Hucitec, 1985.

KOSSOY, Boris. Dicionário bistórico-fotográfico brasileiro:fotógrafos e oficio da fotografia no Brasil (1833-1910). São Paulo: Instituto Moreira Salles, 2002.

KOSSOY, Boris. Fotografia. In: ZANINI,Walter (Org.). História geral da arte no Brasil. São Paulo: Instituto Walther Moreira Salles / Fundação Djalma Guimarães, 1983, v.2, p.867-913.

KOSSOY, Boris. Origens e expansão da fotografia no Brasil. Rio de Janeiro: Funarte, 1980.

KOSSOY, Boris. Panorama da fotografia no Brasil desde 1832. O Estado de S. Paulo, 18.10.1975, p.1-6.

MACHADO,Arlindo. A ilusão especular: introdução à fotografia. São Paulo:Brasiliense / Funarte, 1983.

MENDES, Ricardo. Para que servem as coleções (fotográficas)? In: FOTOGRAFIAS no acervo do museu de arte moderna de São Paulo. São Paulo: MAM, 2002.

MENDES, Ricardo. Pensando a fotografia (a memória). In: BERNARDO, Gustavo; MENDES, Ricardo. Vilém Flusser no Brasil. Rio de Janeiro: Relume-Dumara, 2000.

SAMAIN, Etienne.A "caverna obscura": topografias da fotografia. IMAGENS, Unicamp, v. 1, p. 50-61, abr. 1994.

SAMAIN, Etienne (Org.). O fotográfico. São Paulo: Hucitec/CNPq, 1998. 
VASQUEZ, Pedro. Dom Pedro II e a fotografia no Brasil. Rio de Janeiro: Index, 1984.

VASQUEZ, Pedro Karp. Fotógrafos alemães no Brasil do século XIX. São Paulo: Metalivros, 2000.

VASQUEZ, Pedro Karp. Postaes do Brazil: 1893-1930. São Paulo: Metalivros, 2002.

Artigo apresentado em 8/2003. Aprovado em 9/2003. 
Restauração da fotopintura em tamanho natural de Santos Dumont por Giovanni Sarracino

Yara Lígia Mello Moreira Petrella

Nazareth Coury

Sônia Maria Spigolon

Beatriz Carvalho Ricardo

Trata-se da apresentação dos procedimentos relativos à restauração da fotopintura em tamanho natural de Santos Dumont, feita pelo fotógrafo Giovanni Sarracino. Discute-se todas as fases que abragem desde o diagnóstico, critérios, definição de metodologias de recuperação até a reprodução e tratamento digitalizado da imagem.

PALAVRAS-CHAVE: Fotopintura. Conservação. Restauração digital.

Anais do Museu Paulista. São Paulo. N. Sér.v. 6/7.p. 161-180 (1998-1999). Editado em 2003.

Santos Dumont's natural-sized photo painting restoration by Giovanni Sarracino

Yara Lígia Mello Moreira Petrella

Nazareth Coury

Sônia Maria Spigolon

Beatriz Carvalho Ricardo

It is about the procedures concerning Santos Dumont's natural-sized photo painting restoration, made by the photographer Giovanni Sarracino. All the phases that comprehend from the diagnosis, criteria, definition and restoration methodologies to the reproduction and image-digitalized treatment are discussed.

KEYWORDS: Photo painting. Conservation. Digital Restoration.

Anais do Museu Paulista. São Paulo. N. Sér.v. 6/7. p. 161-180 (1998-1999). Editado em 2003.

Uma História da História da Fotografia

Ricardo Mendes

O ensaio aborda a constituição do campo da pesquisa sobre a fotografia no Brasil, com destaque para o segmento da história da fotografia a partir da década de 1970. A análise procura identificar os principais agentes (pesquisadores, entidades e programas institucionais) e detectar suas interações segundo uma primeira proposta de periodização sobre o tema.

PALAVRAS-CHAVE: Fotografia. História da fotografia. Fotografia brasileira. Historiografia

Anais do Museu Paulista. São Paulo. N. Sér.v. 6/7. p. 183-205 (1998-1999). Editado em 2003.

A story of the History of Photography

Ricardo Mendes

The essay examines the constitution of Brazil's photography research field, with prominence to the segment of History of Photography, starting from the decade of 1970. The analysis tries to identify the main agents (researchers, entities and institutional programs) and detect their interactions according to a first periodization proposal on the subject.

KEYWORDS: Photography, History of Photography, Brazilian Photography, historiography. Anais do Museu Paulista. São Paulo. N. Sér.v. 6/7.p. 183-205 (1998-1999). Editado em 2003

Um balanço bibliográfico e de fontes da estereoscopia

\section{Gavin Adams}

O balanço bibliográfico que se segue é uma reflexão acerca da organização de títulos que tratam da estereoscopia. Menos do que uma tentativa de listar todos os títulos disponíveis em uma bibliografia completa, a presente reflexão quer mapear os tipos principais de publicação de interesse estereoscópico encontrados no curso de sua pesquisa de doutorado. Ademais, o presente balanço quer oferecer uma meditação sobre algumas das particularidades e incidências da bibliografia encontrada, de modo a oferecer ao pesquisador da estereoscopia um guia inicial para seus trabalhos. 